\title{
Palaeoenvironmental change in tropical Australasia over the last 30,000 years - a synthesis by the OZ-INTIMATE group
}

\author{
Jessica M. Reeves ${ }^{\mathrm{a}, *}$, Helen C. Bostock ${ }^{\mathrm{b}}$, Linda K. Ayliffe ${ }^{\mathrm{c}}$, Timothy T. Barrows ${ }^{\mathrm{d}}$, \\ Patrick De Deckker ${ }^{c}$, Laurent S. Devriendt ${ }^{e}$, Gavin B. Dunbar ${ }^{\mathrm{f}}$, Russell N. Drysdale ${ }^{\mathrm{g}}$, \\ Kathryn E. Fitzsimmons ${ }^{\text {h }}$, Michael K. Gagan ${ }^{c}$, Michael L. Griffiths ${ }^{i}$, Simon G. Haberle ${ }^{j}$, \\ John D. Jansen ${ }^{k}$, Claire Krause ${ }^{c}$, Stephen Lewis ${ }^{1}$, Helen V. McGregor ${ }^{\mathrm{e}}$, Scott D. Mooney ${ }^{\mathrm{m}}$, \\ Patrick Moss ${ }^{\mathrm{n}}$, Gerald C. Nanson ${ }^{\mathrm{e}}$, Anthony Purcell ${ }^{\mathrm{c}}$, Sander van der Kaars ${ }^{\mathrm{o}, \mathrm{p}}$ \\ ${ }^{a}$ Centre for Environmental Management, School of Science, Information Technology and Engineering, University of Ballarat, Ballarat, VIC 3353, Australia \\ ${ }^{\mathrm{b}}$ National Institute of Water and Atmospheric Research, Wellington, New Zealand \\ ${ }^{\mathrm{c}}$ Research School of Earth Sciences, The Australian National University, Canberra, Australia \\ ${ }^{\mathrm{d}}$ Geography, College of Life and Environmental Sciences, University of Exeter, United Kingdom \\ e School of Earth and Environmental Sciences, University of Wollongong, Australia \\ ${ }^{\mathrm{f}}$ Antarctic Research Centre, Victoria University of Wellington, New Zealand \\ ${ }^{g}$ Department of Resource Management and Geography, The University of Melbourne, Australia \\ ${ }^{\mathrm{h}}$ Department of Human Evolution, Max Planck Institute for Evolutionary Anthropology, Leipzig, Germany \\ ${ }^{\mathrm{i}}$ Department of Environmental Science, William Patterson University, Wayne, NJ, USA \\ ${ }^{\mathrm{j} S}$ School of Culture, History and Language, The Australian National University, Canberra, Australia \\ ${ }^{\mathrm{k}}$ Department of Physical Geography and Quaternary Geology, Stockholm University, Stockholm, Sweden \\ ${ }^{1}$ Catchment to Reef Research Group, TropWATER, James Cook University, Townsville, Australia \\ ${ }^{\mathrm{m}}$ School of Biological, Earth and Environmental Sciences, University of New South Wales, Sydney, Australia \\ ${ }^{\mathrm{n}}$ Climate Research Group, School of Geography, Planning and Environmental Management, The University of Queensland, Brisbane, Australia \\ ${ }^{\circ}$ Centre for Palynology and Palaeoecology, Department of Geography and Environmental Science, Monash University, Australia \\ ${ }^{\mathrm{p}}$ Cluster Earth E Climate, Department of Earth Sciences, Faculty of Earth and Life Sciences, Vrije Universiteit, De Boelelaan 1085, \\ 1081 HV Amsterdam, The Netherlands
}

\section{A R T I C L E I N F O}

\section{Article history:}

Received 13 March 2012

Received in revised form

16 October 2012

Accepted 21 November 2012

Available online 26 January 2013

\section{Keywords:}

ITCZ

LGM

INTIMATE

Australasia

Indo-Pacific Warm Pool

Tropics

Australian monsoon

\begin{abstract}
A B S T R A C T
The tropics are the major source of heat and moisture for the Australasian region. Determining the tropics' response over time to changes in climate forcing mechanisms, such as summer insolation, and the effects of relative sea level on exposed continental shelves during the Last Glacial period, is an ongoing process of re-evaluation. We present a synthesis of climate proxy data from tropical Australasia spanning the last 30,000 years that incorporates deep sea core, coral, speleothem, pollen, charcoal and terrestrial sedimentary records.

Today, seasonal variability is governed largely by the annual migration of the inter-tropical convergence zone (ITCZ), influencing this region most strongly during the austral summer. However, the position of the ITCZ has varied through time. Towards the end of Marine Isotope Stage (MIS) 3, conditions were far wetter throughout the region, becoming drier first in the south. Universally cooler land and sea-surface temperature (SST) were characteristic of the Last Glacial Maximum, with drier conditions than previously, although episodic wet periods are noted in the fluvial records of northern Australia. The deglacial period saw warming first in the Coral Sea and then the Indonesian seas, with a pause in this trend around the time of the Antarctic Cold Reversal (c. $14.5 \mathrm{ka}$ ), coincident with the flooding of the Sunda Shelf. Wetter conditions occurred first in Indonesia around $17 \mathrm{ka}$ and northern Australia after $14 \mathrm{ka}$. The early Holocene saw a peak in marine SST to the northwest and northeast of Australia. Modern vegetation was first established on Indonesia, then progressively south and eastward to NE Australia. Flores and the Atherton Tablelands
\end{abstract}

\footnotetext{
* Corresponding author. Tel.: +61 353729049.

E-mail address: j.reeves@ballarat.edu.au (J.M. Reeves).
} 
show a dry period around $11.6 \mathrm{ka}$, steadily becoming wetter through the early Holocene. The mid-late Holocene was punctuated by millennial-scale variability, associated with the El Niño-Southern Oscillation; this is evident in the marine, coral, speleothem and pollen records of the region.

Crown Copyright $\odot 2012$ Published by Elsevier Ltd. All rights reserved.

\section{Introduction}

The tropics act as the heat engine for the globe and play an important role in driving centennial- to millennial-scale climate change (Clement et al., 2001). Defining the nature of past tropical climate change since the Last Glacial Maximum (LGM) is important, because it sheds light on the behaviour of Earth's climate system during arguably the most significant climate transition over the last 100,000 years. A better understanding of the likely impacts of natural and anthropogenic climate change on the distribution of tropical rainfall is also crucial for human populations in the Australasian region.

Tropical Australasia (Fig. 1) is defined here as the islands of the Indonesian archipelago, New Guinea and northern Australia. The northern Australian region also incorporates the northern periphery of the extensive arid interior of the continent. The climate systems of tropical Australasia directly affect large catchments within the arid zone (Magee et al., 2004; Cohen et al., 2011; Fitzsimmons et al., 2013), resulting in the imprint of changes in the tropical climate zone substantially further south than might otherwise be expected (Magee et al., 2004; Cohen et al., 2012).

In this paper, we review recent interpretations of climatic changes experienced in tropical Australasia over the past 30,000 years using a wide range of palaeoenvironmental archives, as a contribution to the Australasian-INTIMATE (INTegration of Icecore, MArine and TEerrestrial records) project. In addition to synthesising the regional response through key time intervals, this review identifies significant gaps in our knowledge that constitute targets for future research. This paper is complemented by others in this volume, focussing on the temperate (Petherick et al., 2013) arid interior (Fitzsimmons et al., 2013) and Southern Ocean (Bostock et al., 2013) regions of Australia, and brought together in the Australian region synthesis paper (Reeves et al., 2013). The increase in study sites, improved chronological control and addition of quantitative proxies, such as a coral and speleothems, makes this a significant contribution, building on from work of previous syntheses in this region (e.g. Bowler et al., 1976; Webster and Streten, 1978; Donnelly and Wasson, 1989).

\section{Regional setting}

The present climate of the tropical Australasian region is governed largely by the seasonal movement of the Inter-tropical Convergence Zone (ITCZ). The ITCZ migrates southward into northern Australia during the austral summer (November-March), bringing with it the Australian summer monsoon rain and northwesterly winds in the northern part of the region considered herein. Indonesia and Papua New Guinea (PNG) receive abundant

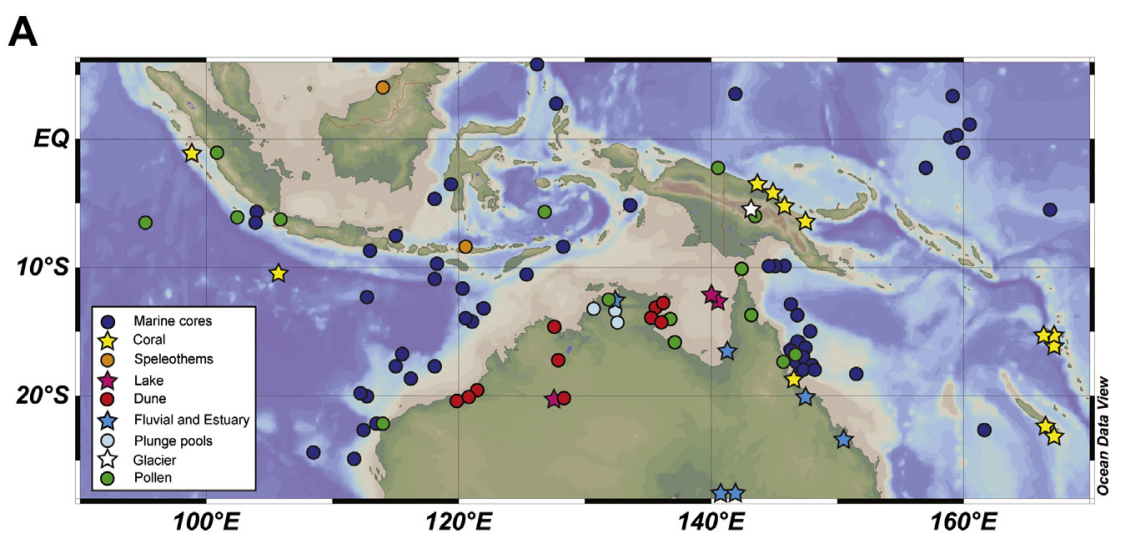

B

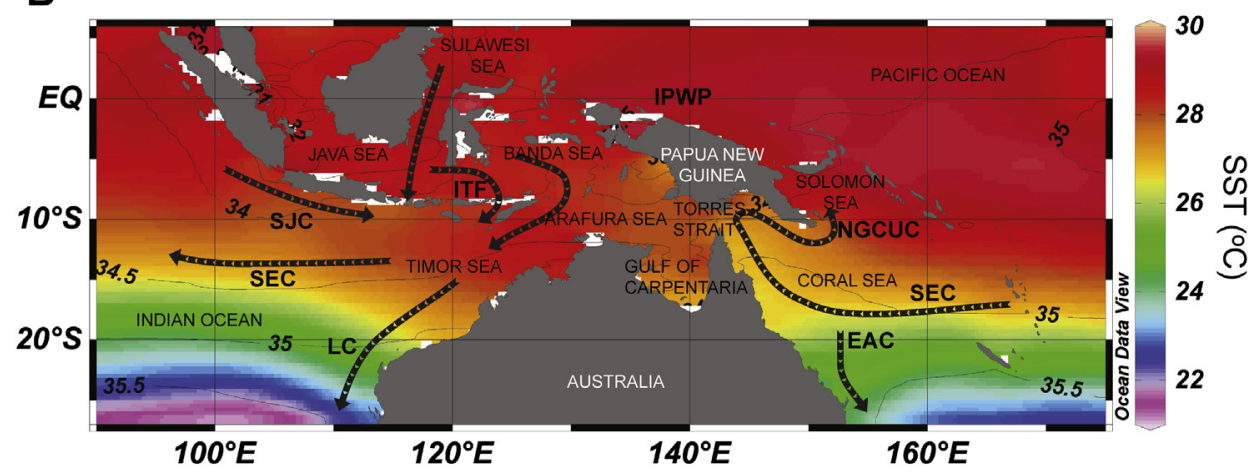

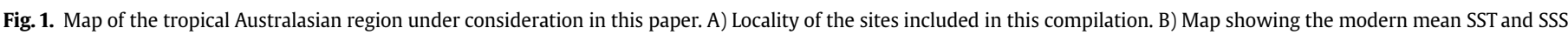
conditions and major surface currents of the region. 
rainfall from both the monsoon and from local orographic influences for more than six months of the year (Webster and Chang, 1997; Wang, 2006). The northeast of Australia also receives moisture from the humid easterlies, sourced from the Coral Sea and equatorial Pacific, which extend the summer wet period in this area. The Great Dividing Range provides a barrier to easterly rain, creating the inland tropical savannah and extending the dunefields of central Australia into the northwest. Rainfall in the northwest is influenced by local sea-surface temperatures (SST) in the Indian Ocean and Timor Sea (Sturman and Tapper, 1996). Tropical cyclones also occur in the summer months over the northern seas and penetrate the continent as rain-bearing depressions. In the austral winter (June-September), the ITCZ migrates northward and is centred over southeast Asia. Consequently, the northern Australian region experiences a warm but dry winter.

The oceanography of the Sahul region is complex due to its bathymetry which is made up of a series of deep basins, shallow shelves and narrow gaps between landmasses (Tomczak and Godfrey, 1994, 2005) (Fig. 1A). The surface currents are strongly influenced by both the trade and monsoonal winds in this region, which shift seasonally due to the movement of the ITCZ and the South Pacific convergence zone (SPCZ). The most relevant surface currents are illustrated in Fig. 1B.

The dominant feature of the northern seas of this region is the Indo-Pacific Warm Pool (IPWP) which is characterised by warm ( $\geq 28^{\circ} \mathrm{C}$; Yan et al., 1992), low salinity (33.5-34.5 psu), low nutrient, surface waters (Fig. 1B; WOA, 2005). The Indonesian Throughflow (ITF) transports between 7 and 18 Sv (Gordon and Fine, 1996) of water from the western Pacific Ocean through the Indonesian archipelago into the Timor Sea and eventually into the Indian Ocean (Wijffels et al., 1996, 2002). This low-salinity flow continues southward, preventing upwelling along the coast of Western Australia (Spooner et al., 2005, 2011). Part of the Throughflow continues with water from the central Indian Ocean to form the Leeuwin Current, which can bring warm water to southern Australia (Godfrey and Ridgway, 1985; Tomczak and Godfrey, 1994). The size and intensity of the IPWP and ITF are closely linked to the El Niño-Southern Oscillation (ENSO) phenomenon and the Indian Ocean Dipole (IOD) (Saji et al., 1999; Webster et al., 1999). Significantly, during dominant La Niña events, the Leeuwin Current can extend along the Southern Australian coast as far east as Tasmania in winter (De Deckker et al., 2012).

To the east of Australia, the East Australian Current (EAC) is the main surface-water current. The EAC is sourced from the southern arm of the South Equatorial Current (SEC), which brings warm (25$\left.28{ }^{\circ} \mathrm{C}\right)$, saline $(\sim 35 \%)$, low nutrient surface waters, into the Coral Sea (WOA, 2005). The SEC is a wind-driven current forced by the equatorial trade winds. The SEC bifurcates at its point of contact with the Queensland Plateau; the northern arm of the EAC downwells and flows along the Great Barrier Reef and around the Coral Sea, then northward through the Vitiaz Strait and along the coast of PNG, before turning eastward and flowing along the equator as the Equatorial Undercurrent (Fine et al., 1994). The southern arm of the SEC flows south along the east coast of Australia. As a result of a strong connection to the trade winds, the EAC is also affected by ENSO (McPhaden et al., 1992).

\section{Methods}

A combination of palaeoclimate archives, integrating deep sea cores, corals, speleothems, geomorphology, pollen and charcoal from terrestrial environments, are used to determine the timing and extent of past changes. The records included in this compilation are representative, rather than comprehensive, of those available (Table 1). The selection criteria for the Australasian-
Table 1

List of sites utilised in this study and shown on Fig. 1.

\begin{tabular}{lrrl}
\hline Site & Latitude & Longitude & Record \\
\hline SO139-74 KL & -6.54 & 103.83 & Alkenone \\
S New Caledonia & -23.00 & 167.00 & Coral \\
$\begin{array}{l}\text { Southwest Lagoon, } \\
\quad \text { New Caledonia }\end{array}$ & -22.48 & 166.45 & Coral \\
$\begin{array}{l}\text { Amedee Is, } \\
\quad \text { New Caledonia }\end{array}$ & -22.47 & 166.47 & Coral \\
$\quad$ & & \\
Orpheus, GBR & -18.62 & 146.50 & Coral \\
Papeete, Tahiti & -17.53 & -149.57 & Coral \\
Vanuatu & -16.00 & 167.00 & Coral \\
Espiritu Santo, & -15.25 & 166.82 & Coral \\
$\quad$ Vanuatu & & & \\
Christmas Is & -10.42 & 105.65 & Coral \\
& & & \\
Huon Peninsula, PNG & -6.42 & 147.50 & Coral \\
Madang, PNG & -5.22 & 145.78 & Coral \\
Laing island, PMG & -4.17 & 144.87 & Coral \\
Muschu, PNG & -3.42 & 143.57 & Coral
\end{tabular}

\begin{tabular}{|c|c|c|c|}
\hline Mentawai, Indonesia & -1.12 & 98.73 & Coral \\
\hline Burdekin Delta & -20.00 & 147.50 & Estuary \\
\hline Innamincka, SA & -27.73 & 140.73 & Fluvial \\
\hline Chookoo, QLD & -27.58 & 141.88 & Fluvial \\
\hline Fitzroy River, QLD & -23.38 & 150.50 & Fluvial \\
\hline $\begin{array}{l}\text { Gilbert River } \\
\text { Delta, QLD }\end{array}$ & -16.55 & 141.27 & Fluvial \\
\hline Lily Ponds, NT & -14.32 & 132.47 & Fluvial \\
\hline Waterfall Ck, NT & -13.42 & 132.42 & Fluvial \\
\hline Wangi Gorge, NT & -13.15 & 130.68 & Fluvial \\
\hline V33-65 & -22.73 & 112.58 & Forams \\
\hline MD97-2125 & -22.50 & 161.50 & Forams \\
\hline FR10/95-17 & -22.13 & 113.50 & Forams \\
\hline MD00-2361 & -22.08 & 113.48 & Forams \\
\hline FR10/95-14 & -20.05 & 112.66 & Forams \\
\hline FR2/96-27 & -18.56 & 116.27 & Forams \\
\hline FR4/92-PC2 & -18.10 & 147.22 & Forams \\
\hline FR4/92-PC3 & -18.03 & 147.33 & Forams \\
\hline FR4/92-PC32 & -17.99 & 148.04 & Forams \\
\hline FR4/92-PC24a & -17.87 & 146.89 & Forams \\
\hline FR4/92-PC4 & -17.86 & 147.58 & Forams \\
\hline FR4/92-PC25 & -17.73 & 147.10 & Forams \\
\hline FR4/92-PC5 & -17.70 & 147.83 & Forams \\
\hline FR10/95-11 & -17.64 & 115.00 & Forams \\
\hline FR4/92-PC11 & -17.57 & 147.35 & Forams \\
\hline FR4/92-PC23 & -17.54 & 146.76 & Forams \\
\hline FR4/92-PC6 & -17.53 & 148.08 & Forams \\
\hline FR4/92-PC16 & -17.43 & 146.89 & Forams \\
\hline FR4/92-PC31 & -17.41 & 147.62 & Forams \\
\hline FR4/92-PC12 & -17.27 & 147.14 & Forams \\
\hline FR4/92-PC22a & -17.17 & 146.62 & Forams \\
\hline FR4/92-PC10 & -17.11 & 147.39 & Forams \\
\hline FR4/92-PC13 & -16.95 & 146.92 & Forams \\
\hline FR4/92-PC9 & -16.80 & 147.18 & Forams \\
\hline FR4/92-PC14 & -16.72 & 146.73 & Forams \\
\hline FR4/92-PC42 & -16.65 & 147.43 & Forams \\
\hline FR4/92-PC8 & -16.55 & 146.98 & Forams \\
\hline ODP762A & -16.54 & 115.54 & Forams \\
\hline FR4/92-PC15 & -16.44 & 146.89 & Forams \\
\hline FR4/92-PC39 & -16.38 & 147.22 & Forams \\
\hline FR5/90-PC7 & -16.35 & 146.11 & Forams \\
\hline FR5/90-PC32 & -16.33 & 146.30 & Forams \\
\hline FR5/90-PC9 & -16.30 & 146.19 & Forams \\
\hline FR4/92-PC30 & -16.28 & 146.76 & Forams \\
\hline FR5/90-PC31 & -16.26 & 146.40 & Forams \\
\hline FR4/92-PC40 & -16.21 & 147.48 & Forams \\
\hline FR5/90-PC30 & -16.18 & 146.55 & Forams \\
\hline FR4/92-PC34 & -16.16 & 146.33 & Forams \\
\hline FR4/92-PC7 & -16.11 & 147.02 & Forams \\
\hline FR4/92-PC35 & -16.02 & 146.55 & Forams \\
\hline FR4/92-PC38 & -15.93 & 147.28 & Forams \\
\hline FR4/92-PC36 & -15.83 & 146.82 & Forams \\
\hline
\end{tabular}

References

Luckge et al. 2009

Corrège et al., 2004

Corrège et al., 2004

Corrège et al., 2000

Gagan et al., 1998

Bard et al., 2010

Corrège, 2006

Beck et al., 1992

Woodroffe et al. 2003

Tudhope et al., 2001 Tudhope et al., 2001 Tudhope et al., 2001

Abram et al., 2009; McGregor and Gagan, 2004 McGregor et al., 2008 Abram et al., 2009

Fielding et al., 2006

Nanson et al., 2008

Nanson et al., 2008

Croke et al., 2010

Nanson et al., 1991

Nott and Price, 1999

Nott et al., 1996

Nott et al., 1996

Martinez et al., 1999

Tachikawa et al.

2009

Martinez et al., 1999

Spooner et al., 2011

Martinez et al., 1999

Martinez et al., 1999

Dunbar et al., 2000

Dunbar et al., 2000

Dunbar et al., 2000

Dunbar et al., 2000

Dunbar et al., 2000

Dunbar et al., 2000

Dunbar et al., 2000

Martinez et al., 1999

Dunbar et al., 2000

Dunbar et al., 2000

Dunbar et al., 2000

Dunbar et al., 2000

Dunbar et al., 2000

Dunbar et al., 2000

Dunbar et al., 2000

Dunbar et al., 2000

Dunbar et al., 2000

Dunbar et al., 2000

Dunbar et al., 2000

Dunbar et al., 2000

Dunbar et al., 2000

Martinez et al., 1999

Dunbar et al., 2000

Dunbar et al., 2000

Dunbar et al., 2000

Dunbar et al., 2000

Dunbar et al., 2000

Dunbar et al., 2000

Dunbar et al., 2000

Dunbar et al., 2000

Dunbar et al., 2000

Dunbar et al., 2000

Dunbar et al., 2000

Dunbar et al., 2000

Dunbar et al., 2000

Dunbar et al., 2000

(continued on next page) 
Table 1 (continued)

\begin{tabular}{|c|c|c|c|c|}
\hline Site & Latitude & Longitude & Record & References \\
\hline FR4/92-PC37 & -15.66 & 147.07 & Forams & Dunbar et al., 2000 \\
\hline V28-342 & -14.10 & 120.50 & Forams & Martinez et al., 1999 \\
\hline FR10/95-5 & -14.01 & 121.03 & Forams & Martinez et al., 1999 \\
\hline MD01-2378 & -13.08 & 121.78 & Forams & $\begin{array}{l}\text { Holbourn et al., 2005; } \\
\text { Xu et al., } 2010\end{array}$ \\
\hline FR2/96-17 & -12.25 & 112.74 & Forams & Martinez et al., 1999 \\
\hline MD97-2166 & -11.58 & 120.27 & Forams & Moreno et al., 2008 \\
\hline MD98-2170 & -10.59 & 125.39 & Forams & Stott et al., 2004 \\
\hline MV26-0403-66JPC & -10.00 & 145.15 & Forams & Jorry et al., 2008 \\
\hline MD97-2134 & -9.90 & 144.65 & Forams & $\begin{array}{l}\text { de Garidel-Thoron } \\
\text { et al., } 2004\end{array}$ \\
\hline MV25-0403-33JPC & -9.87 & 145.73 & Forams & Jorry et al., 2008 \\
\hline MD05-2940C2 & -9.79 & 145.73 & Forams & Jorry et al., 2008 \\
\hline MD98-2165 & -9.65 & 118.33 & Forams & Levi et al., 2007 \\
\hline GeoB10053-7 & -8.68 & 112.87 & Forams & Mohtadi et al., 2011 \\
\hline SHI-9016 & -8.46 & 128.24 & Forams & Spooner et al., 2005 \\
\hline 13GGC & -7.40 & 115.20 & Forams & Linsley et al., 2010 \\
\hline BA9403 & -5.82 & 104.03 & Forams & Murgese et al., 2008 \\
\hline MD98-2176 & -5.00 & 133.43 & Forams & Stott et al., 2004 \\
\hline MD98-2162 & -4.69 & 117.90 & Forams & Visser et al., 2003 \\
\hline 70GGC & -3.57 & 119.38 & Forams & Linsley et al., 2010 \\
\hline MW91-15 & 0.02 & 158.94 & Forams & $\begin{array}{l}\text { Patrick and } \\
\text { Thunell, } 1997\end{array}$ \\
\hline MD98-2181 & 6.00 & 126.00 & Forams & Stott et al., 2007 \\
\hline $\begin{array}{l}\text { Lake Carpentaria } \\
\quad \text { GC2 }\end{array}$ & -12.52 & 140.35 & Lake & $\begin{array}{l}\text { Torgersen et al., } 1985 \text {, } \\
1988\end{array}$ \\
\hline $\begin{array}{l}\text { Lake Carpentaria } \\
\quad \text { MD32 }\end{array}$ & -12.30 & 139.97 & Lake & $\begin{array}{l}\text { Chivas et al., 2001; } \\
\text { Reeves et al., 2008; } \\
\text { Devriendt, } 2011\end{array}$ \\
\hline $\begin{array}{l}\text { Lake Gregory, } \\
\text { xWA }\end{array}$ & -20.25 & 127.50 & Lake/Dune & $\begin{array}{l}\text { Veth et al., 2009; } \\
\text { Fitzsimmons } \\
\text { et al., 2012; } \\
\text { Wyrwoll and } \\
\text { Miller, } 2001\end{array}$ \\
\hline $\begin{array}{c}\text { Cabbage Tree } \\
\text { Creek, WA }\end{array}$ & -16.25 & 128.42 & Dune & Wende et al., 1998 \\
\hline $\begin{array}{l}\text { Carpentaria } \\
\text { dune field }\end{array}$ & -13.7 & 136.2 & Dune & $\begin{array}{l}\text { Lees et al., 1990; Lees } \\
\text { and Lu, 1991, } 1992\end{array}$ \\
\hline Cape Range, WA & -22.17 & 113.83 & Pollen & $\begin{array}{l}\text { van der Kaars and } \\
\text { De Deckker, } 2002\end{array}$ \\
\hline $\begin{array}{l}\text { Four Mile } \\
\text { Billabong, NT }\end{array}$ & -13.85 & 136.78 & Pollen & $\begin{array}{l}\text { Shulmeister and } \\
\text { Lees, } 1995\end{array}$ \\
\hline $\begin{array}{l}\text { Lynch's } \\
\text { Crater, QLD }\end{array}$ & -17.37 & 145.70 & Pollen & $\begin{array}{l}\text { Kershaw, 1981; } \\
\text { Turney et al., } 2006\end{array}$ \\
\hline Lake Euramoo, QLD & -17.17 & 146.63 & Pollen & Haberle, 2005 \\
\hline Lake Walala, NT & -15.68 & 137.03 & Pollen & Prebble et al., 2005 \\
\hline $\begin{array}{l}\text { Three Quarter } \\
\text { Mile Lake, QLD }\end{array}$ & -12.5 & 143 & Pollen & Luly et al., 2006 \\
\hline ODP820 & -16.63 & 146.30 & Pollen & $\begin{array}{l}\text { Moss and } \\
\text { Kershaw, } 2007\end{array}$ \\
\hline BAR94-25 & -6.43 & 95.32 & Pollen & $\begin{array}{l}\text { van der Kaars } \\
\text { et al., } 2012\end{array}$ \\
\hline $\begin{array}{l}\text { Rawa Danau, } \\
\text { Java }\end{array}$ & -6.18 & 105.95 & Pollen & $\begin{array}{l}\text { van der Kaars } \\
\text { et al., 2001; } \\
\text { Turney et al., } 2006\end{array}$ \\
\hline BAR94-42 & -6.07 & 102.42 & Pollen & $\begin{array}{l}\text { van der Kaars } \\
\text { et al., } 2010\end{array}$ \\
\hline Sirunki, PNG & -6.00 & 143.50 & Pollen & $\begin{array}{l}\text { Walker and } \\
\text { Flenley, } 1979\end{array}$ \\
\hline SHI-9014 & -5.77 & 126.97 & Pollen & $\begin{array}{l}\text { van der Kaars } \\
\text { et al., } 2000\end{array}$ \\
\hline $\begin{array}{l}\text { Lake Hordorli, } \\
\text { Irian Jaya }\end{array}$ & -2.33 & 140.50 & Pollen & Hope and Tulip, 1994 \\
\hline $\begin{array}{l}\text { Danua di Atas, } \\
\text { Sumatra }\end{array}$ & -1.07 & 100.77 & Pollen & $\begin{array}{l}\text { Newsome and } \\
\text { Flenley, } 1988\end{array}$ \\
\hline $\begin{array}{l}\text { South Alligator } \\
\text { River, NT }\end{array}$ & -12.45 & 132.47 & Pollen & Woodroffe et al., 1985 \\
\hline Badu, Torres Strait & -10.12 & 142.17 & Pollen & Rowe, 2007 \\
\hline Mua, Torres Strait & -10.18 & 142.25 & Pollen & Rowe, 2007 \\
\hline Liang Luar, Flores & -8.53 & 120.43 & Speleothem & $\begin{array}{l}\text { Griffiths et al., 2009, } \\
\text { 2010a,b; } \\
\text { Lewis et al., } 2011\end{array}$ \\
\hline $\begin{array}{l}\text { Gunung Buda NP, } \\
\text { Borneo }\end{array}$ & 4.00 & 114.00 & Speleothem & Partin et al., 2007 \\
\hline Mt Giluwe, PNG & -6.05 & 143.88 & Glacier & Barrows et al., 2011 \\
\hline
\end{tabular}

INTIMATE program include records that are continuous, cover the period of interest (30-0 ka), of centennial to millennial scale resolution and contain robust chronologies. Discontinuous records that are well-dated, which correspond to a key interval of change and have a reconcilable climate proxy are also included; such records are the most valid for tropical inland Australia, where few continuous records exist. Unless otherwise discussed, we have accepted the original authors' interpretations of the records. The records included are listed in Table 1, with locations shown in Fig. 1. The proxy data from records we identify as being characteristic are referred throughout. Where the discussion refers to "warmer" or "wetter", it is in relation to the previous period, rather than the present day, unless otherwise stated. "Wet" refers to both increased run-off (e.g. fluvial, pollen records) and decreased salinity (e.g. marine sea-surface salinity - SSS, lacustrine records).

The chronology for each of the records has been defined using a range of methods: ${ }^{14} \mathrm{C}$ AMS (accelerator mass spectrometry), $\mathrm{U} / \mathrm{Th}$, optically stimulated luminescence (OSL), thermoluminesence (TL) and isotope stratigraphy. In order to reliably compare different types of records dated using different techniques, these have been calibrated to $1950 \mathrm{AD}$, taking into consideration reservoir and other corrections, and referred to as "ka" throughout. Readers should refer to the original papers to clarify the chronological methodology applied. For this exercise, we consider 30$18 \mathrm{ka}$ to be the glacial period, including the LGM (21-18 ka), $18-12 \mathrm{ka}$ to be the deglacial and $12-0 \mathrm{ka}$ to be the Holocene. The Holocene has been divided into early (12-8 ka), mid (8-4 ka) and late (4-0 ka) phases.

\section{Marine records}

Many marine sediment cores have been collected from both the west and east of the region and provide relatively continuous records. These cores have been analysed for a range of microfossils, geochemistry, pollen and clay content to determine environmental changes over the last $30 \mathrm{kyr}$. Cores to the north and west of Australia contain substantial terrigenous influx from tropical rivers and relatively high biological productivity, and provide medium to high resolution $(>5 \mathrm{~cm} / \mathrm{ka}$ ) records. However, cores from the Coral Sea have a much lower resolution due to the relatively reduced terrigenous influx, especially during the LGM and Holocene (Dunbar et al., 2000; Page et al., 2003) and lower productivity due to the oligotrophic conditions. Two representative cores from the Timor Sea and the Coral Sea are presented in Fig. 2.

Sea-surface temperature (SST) estimates have been determined from a range of proxies including $\delta^{18} \mathrm{O}$ and/or $\mathrm{Mg} / \mathrm{Ca}$ of planktonic foraminifera, alkenones and foraminiferal assemblages in conjunction with the modern analogue technique (Barrows and Juggins, 2005). These proxies assume that organisms did not change their habitats, and the calibrations remain the same between the modern and the Last Glacial. There are offsets between the different SST methods since some of the organisms used in the SST proxies grow at different depths in the upper water column. This is taken into consideration in our interpretation.

During the LGM, when sea level was around $125 \mathrm{~m}$ lower than today (e.g. Yokoyama et al., 2001), much more land was exposed on the Sunda Shelf, such that the proportion of ocean in the region was reduced to $64 \%$, as opposed to $78 \%$ today (Fig. 3; De Deckker et al., 2002; De Deckker and Yokoyama, 2009; Lewis et al., 2013). The ratio of land to ocean modified the seasonal variability and vertical profile of the ITF (De Deckker et al., 2002). In addition, Australia and New Guinea were connected to form one landmass (e.g. Walker, 1972; Chappell and Grindrod, 1983). These factors had a significant effect on the circulation of oceanic surface currents and the 


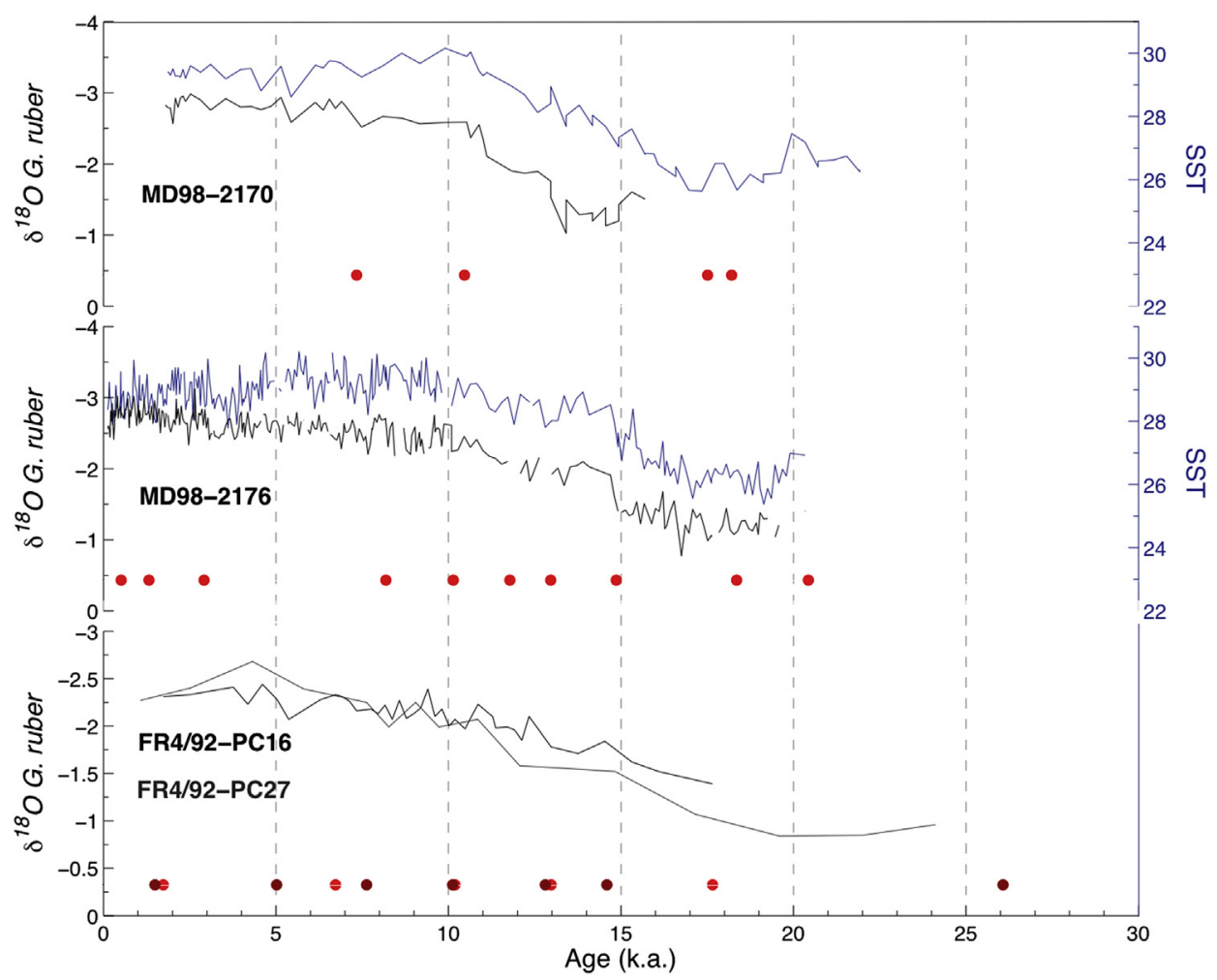

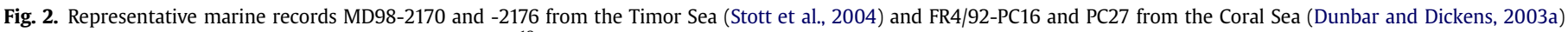
showing SST estimates over the last $>20,000$ years from $\delta^{18} \mathrm{O}$ of G. ruber.

extent of the Indo-Pacific Warm Pool, and in conjunction with changes in insolation, greatly impacted the regional climatic conditions. This sea-level lowering would have caused a reduction in the volume of water transported through the ITF, by perhaps as much 30\% (Zuvela-Aloise, 2005), significantly altering oceanic circulation (De Deckker et al., 2002).

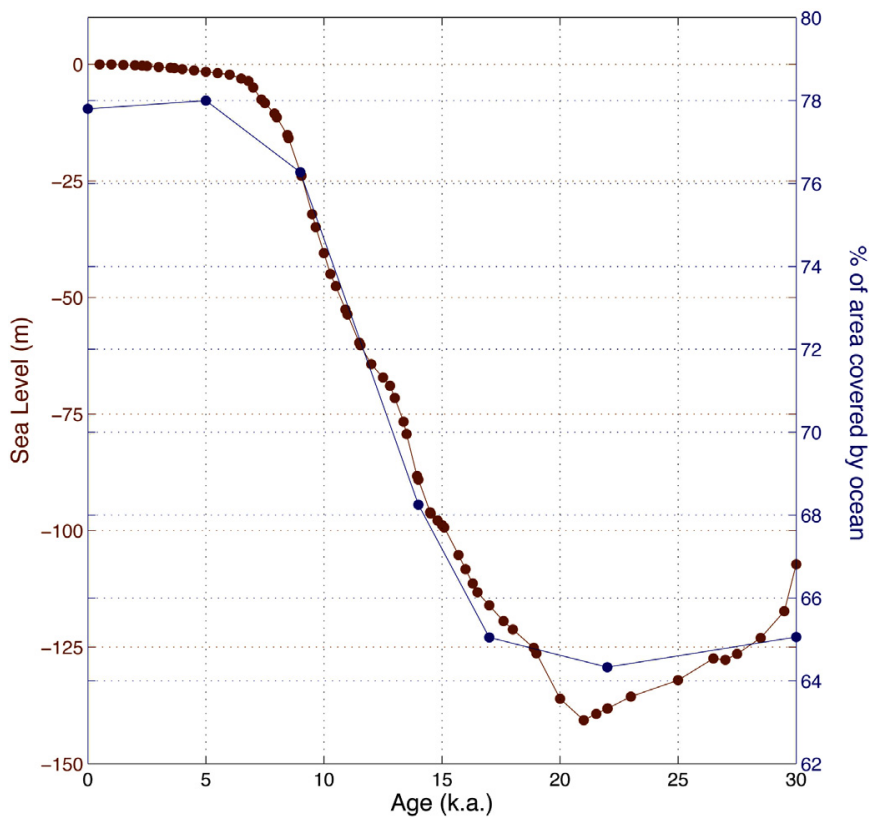

Fig. 3. Plot of relative sea level and percentage ocean area for region under consideration (bounded by $23.5^{\circ} \mathrm{N}, 160^{\circ} \mathrm{E}, 23.5^{\circ} \mathrm{S}$ and $95^{\circ} \mathrm{E}$ ), through the last $30 \mathrm{ka}$.
Sea-surface temperature estimates from $\mathrm{Mg} / \mathrm{Ca}$ ratios of planktonic foraminifer Globigerinoides ruber and foraminiferal assemblages from a suite of marine cores from the north and west of the region suggest cooling by $1-3{ }^{\circ} \mathrm{C}$ during the LGM (Thunell et al., 1994; Lea et al., 2000; Ding et al., 2002; Stott et al., 2002; Visser et al., 2003; Barrows and Juggins, 2005; Spooner et al., 2005; Levi et al., 2007; Stott et al., 2007; Xu et al., 2010). A lower thermal gradient between surface and thermocline waters is also projected (Spooner et al., 2005; Xu et al., 2010). Sea-surface salinity (SSS) was as much as 2 units higher (Barmawidjaja et al., 1993; Martinez et al., 1997; De Deckker et al., 2002; Stott et al., 2002). In parallel, wind and rainfall patterns were quite different during the LGM, associated with weakening of the monsoon (Gingele et al., 2001; De Deckker et al., 2002) and effecting a reduction in discharge from the main river systems (Gingele and De Deckker, 2004; Nanson et al., 2008).

There is evidence that the altered ITF resulted in increased upwelling of nutrient-rich waters and increased surface productivity during the glacial period in the Timor Sea (Müller and Opdyke, 2000; Holbourn et al., 2005) along with a stronger Java upwelling system (Martinez et al., 1998, 1999; Gingele et al., 2002). This cooling of the IPWP during the glacial period (Stott et al., 2002) and upwelling of the Timor Sea is analogous to weakening of the monsoon (Spooner et al., 2005) and resulted in reduced rainfall over tropical Australia (Gingele and De Deckker, 2004; van der Kaars et al., 2006).

Palaeotemperature estimates from foraminiferal assemblages also suggest that there was little change in SSTs in the Coral Sea between the $\operatorname{LGM}\left(\sim 1^{\circ} \mathrm{C}\right.$ cooler) and present (Anderson et al., 1989; Barrows and Juggins, 2005). Oxygen isotopes from G. ruber in cores from the Queensland Trough and the northern Coral Sea however, suggest up to $2.5^{\circ} \mathrm{C}$ of cooling and higher salinity during the LGM (Dunbar and Dickens, 2003a; de Garidel-Thoron et al., 2004; Jorry et al., 2008). A reduced SST gradient between the eastern and 
western tropical Pacific (Koutavas et al., 2002) and a shift of the ITCZ to the north resulted in weaker trade winds and thus a reduced SEC, and there is no evidence for the SPCZ (Barrows and Juggins, 2005). The EAC was present off central Queensland during the LGM, although significantly reduced in extent (Bostock et al., 2006).

Sea-surface temperature in the Coral Sea warmed as early as $20 \mathrm{ka}$, preceding Termination 1 , the rise in atmospheric $\mathrm{CO}_{2}$ (Tachikawa et al., 2009) and increasing air temperatures over Antarctica (Monnin et al., 2001). This suggests that the SST rise was not caused by the increasing $\mathrm{CO}_{2}$, but rather by changes in local summer insolation (Tachikawa et al., 2009), which at $\sim 20$ ka was at a maximum in the Southern Hemisphere. Seawater $\delta^{18} \mathrm{O}$ decreased dramatically during Meltwater Pulse 1A (MWP-1A; Weaver et al., 2003) from 18 to $15 \mathrm{ka}$, then paused around the time of the Antarctic Cold Reversal (ACR) (15-13.5 ka) (Dunbar et al., 2000; Dunbar and Dickens, 2003a; Jorry et al., 2008; Tachikawa et al., 2009). The coupled pollen $-\delta^{18} \mathrm{O}$ record from offshore Cairns shows the response in the pollen lagging the isotopic decline by some $2 \mathrm{k}$ (Peerdeman et al., 1993; Moss and Kershaw, 2007).

In the Bonaparte Gulf of the northwest shelf of Australia, the deglaciation was marked by rapid sea-level rise of as much as $15 \mathrm{~m}$ within the 500 years following $19 \mathrm{ka}$ (Yokoyama et al., 2001; De Deckker and Yokoyama, 2009). In other cores from the Indian Ocean, this is followed by a dramatic decrease in foraminifer $\delta^{18} \mathrm{O}$ at 15 ka (Patrick and Thunell, 1997; Visser et al., 2003; Holbourn et al., 2005; Spooner et al., 2005; Levi et al., 2007; Stott et al., 2007; Murgese et al., 2008).

The $\delta^{18} \mathrm{O}$ varies little in all of the marine cores in the tropical region during the ACR and Younger Dryas (YD) period of 14-12 ka (Patrick and Thunell, 1997; Dunbar et al., 2000; Dunbar and Dickens, 2003a; Visser et al., 2003; de Garidel-Thoron et al., 2004; Spooner et al., 2005; Holbourn et al., 2005; Stott et al., 2007; Jorry et al., 2008; Murgese et al., 2008; Tachikawa et al., 2009).

Most of the ITF pathways were flooded by rising sea level by 14$13 \mathrm{ka}$ (De Deckker et al., 2002), concurrent with a warming of $3{ }^{\circ} \mathrm{C}$ in the western IPWP (Linsley et al., 2010). The monsoon was reinvigorated as early as $15 \mathrm{ka}$ and would have been well developed around 13-12 ka, as evidenced both by marine SSS records and terrestrial discharge to the Indian Ocean (Gingele et al., 2002; Spooner et al., 2005; Murgese et al., 2008). Therefore the response in the $\delta^{18} \mathrm{O}$ record between 14 and $12 \mathrm{ka}$ is probably a combination of both increased temperature and decreased salinity, through increased precipitation in the region.

$\mathrm{Mg} / \mathrm{Ca}$ estimates of SST indicate that the early Holocene was the warmest period during the last $30 \mathrm{ka}$, with SSTs $0.5-1{ }^{\circ} \mathrm{C}$ warmer than present in the northwest (Fig. 3; Visser et al., 2003; Stott et al., 2004; Xu et al., 2010) with an increase in the freshwater influx and the expansion of the western boundary of the IPWP (Linsley et al., 2010). The timing of this early Holocene maximum is also coincident with the local insolation minimum and approximately concurrent with the northern hemisphere thermal maximum (Linsley et al., 2010). This early Holocene temperature maximum also coincides with a large supply of terrigenous material offshore the northwest shelf (Gingele et al., 2001) as well as a flux of silicate and carbonate into the Queensland slope and trough (between 12 and $7 \mathrm{ka}$ ) caused by the flooding of the continental shelf (Dunbar et al., 2000; Page et al., 2003; Dunbar and Dickens, 2003a,b). In addition, the re-initiation of the Great Barrier Reef (GBR) commenced around 8-9 ka (Thom and Chappell, 1975). The EAC was re-invigorated by $\sim 11$ ka when SSTs reached their Holocene/modern values (Bostock et al., 2006) and the eastwest SST gradient in the tropical Pacific was re-established resulting in an increase in the tropical trade winds (Koutavas et al., 2002; Stott et al., 2002; Gagan et al., 2004) and increased flow of the SEC into the Coral Sea. The large estuaries of northern Australia were also formed during the late deglacial to early Holocene period (157 ka) (Grindrod et al., 1999, 2002). Rapid colonisation of mangroves followed the flooding of the shelf during the transgression until marine and terrigenous sediments infilled the embayments and sea-level stabilised (Woodroffe et al., 1985).

After a peak in SST during the early and mid-Holocene most of the marine core records indicate a small cooling in the late Holocene (Fig. 3; Stott et al., 2004; De Garidel-Thoron et al., 2004; Tachikawa et al., 2009; Linsley et al., 2010). This is in contrast to the decreasing $\delta^{18} \mathrm{O}$ G. ruber throughout the Holocene and has been attributed to a decreasing salinity by as much as 1.5 units due to changes in the tropical hydrological cycle (Stott et al., 2004).

\section{Corals}

Trace element ratios (e.g. $\mathrm{Sr} / \mathrm{Ca})$ and stable isotope $\left(\delta^{18} \mathrm{O}\right)$ records from corals provide a rare source of information on the seasonal, decadal, and centennial climatic variations in the tropics. Records for the most recent centuries are generally obtained from living corals, whereas further back in time records are obtained from stand-alone, well preserved, precisely dated fossil corals (e.g., McGregor, 2011). Thus far, coral records have provided a detailed "snapshot" of the climate for the time in which they lived, typically several decades to several centuries in duration, and with advances in radiometric dating, multiple fossil coral heads have been overlapped (within dating errors) to give longer, more continuous records for the pre-industrial period (Cobb et al., 2003). The seasonal resolution of coral records has been particularly useful in reconstructing the ENSO, one of the key climate drivers for the Australasian region. ENSO reconstructions and coral-based sea-surface temperature reconstructions are skewed towards the Holocene, though there are some records from glacial times (e.g. Tudhope et al., 2001). In addition to direct climate reconstruction, downcore observations of coral species abundance and dating of these corals document glacial-interglacial sea level history and the response of reef ecological response to these changes. A composite SST anomaly reconstruction based on records derived from wellpreserved Holocene corals is presented in Fig. 4.

During the LGM and much of the deglacial period, the GBR shelf (on average $70 \mathrm{~m}$ below present sea level) was exposed and there was no coral growth. Recent bathymetric surveys have discovered a series of patch, fringing and ribbon reefs at 50-100 m water depth (Abbey et al., 2011), which presumably grew after they were

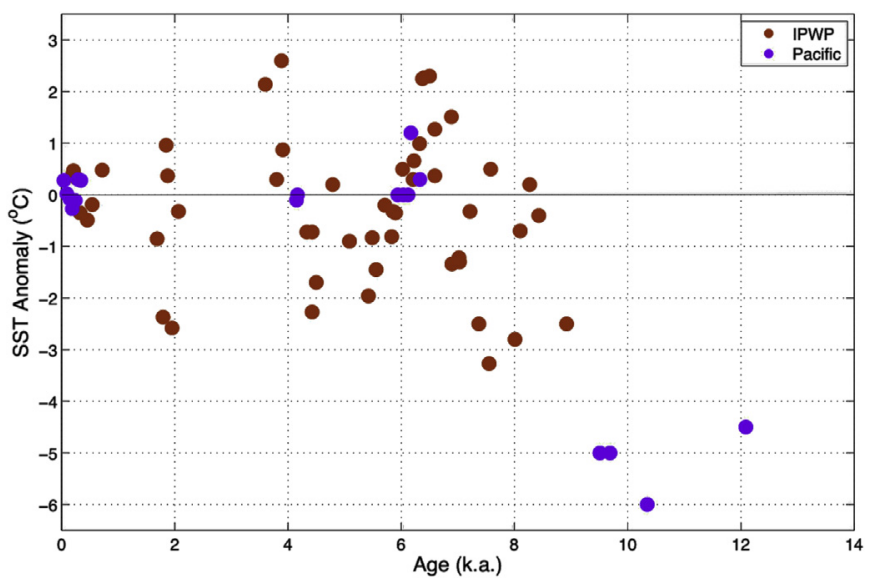

Fig. 4. Composite plot of coral records from the tropical Australasian region, through the Holocene. The corals from within the IPWP have been differentiated from those of the broader Pacific region, some of which lie significantly to the south (e.g. Vanuatu, New Caledonia). 
submerged between 11 and $15 \mathrm{ka}$. Similar reefs in the Gulf of Carpentaria at 25-30 m depth have been dated at 10.5-7.0 ka (Harris et al., 2008). All these reefs were eventually drowned by the rapidly rising sea. Despite the flooding of the main shelf as early as $12 \mathrm{ka}$, the Pleistocene foundations of the vast majority of modern reefs were only inundated at $8.5 \mathrm{ka}$ and reef accretion commenced rapidly thereafter (Hopley et al., 2007). This rapid reef growth continued until $5.5 \mathrm{ka}$, followed by a hiatus/or a slowing of reef growth. A second period of reef accretion initiated around $2.3 \mathrm{ka}$ and continues today (Perry and Smithers, 2011). The reason for the hiatus between these two periods of rapid growth is unknown, although hiatuses over similar timeframes have also been discovered in Moreton Bay, southern Queensland which was linked to the onset of modern ENSO conditions (Lybolt et al., 2010). Moreover, the initiation of several incipient reefs on the GBR in the last 1200 years BP has been linked to the recent sea-level fall (Lewis et al., 2012).

With few exceptions (e.g. Hathorne et al., 2011), measurements of $\mathrm{Sr} / \mathrm{Ca}$ in corals from Vanuatu (Beck et al., 1992, 1997; Corrège et al., 2004), PNG (McCulloch et al., 1996) and Tahiti (Asami et al., 2009; DeLong et al., 2010) indicate that the tropical western Pacific was $\sim 3-6{ }^{\circ} \mathrm{C}$ cooler during the late deglacial period and YD interval, in contrast with SST proxies from the deep sea cores. However, the coral $\mathrm{Sr} / \mathrm{Ca}$ records have recently been re-scaled using a modified $\mathrm{Sr} / \mathrm{Ca}-\mathrm{SST}$ relationship that suggests cooling of $\sim 2-$ $4{ }^{\circ} \mathrm{C}$ (Gagan et al., 2012). An analysis of $\mathrm{Sr} / \mathrm{Ca}$ in corals exposed on 8.5-7.9 ka raised reefs on the island of Alor in eastern Indonesia indicate that SSTs cooled by $\sim 2{ }^{\circ} \mathrm{C}$ during the so-called $8.2 \mathrm{ka}$ event (Gagan et al., 2004).

Coral records at the southwestern and southeastern edge of the IPWP (Mentawai Islands, Sumatra and Mushu/Koil islands, PNG respectively; Figs. $1 \mathrm{~A}$ and 4 ) suggest $1-2{ }^{\circ} \mathrm{C}$ cooler intervals during the Holocene prior to $6.8 \mathrm{ka}$ and between 5.5 and $4.3 \mathrm{ka}$, interpreted as a contraction of the IPWP (Abram et al., 2009). Evidence from fossil corals from the southeastern IPWP and the Coral Sea at this time also suggest less frequent, and less extreme, El Niño events compared with today (Corrège et al., 2000; Tudhope et al., 2001; McGregor and Gagan, 2004; Gagan et al., 2004). The contraction of the IPWP seen in the corals supports other evidence from around the region for a shift in the ITCZ to a more northerly position during the middle Holocene, similar to the modern austral winter position (Haug et al., 2001; McGregor and Gagan, 2004; Abram et al., 2009). The southern branch of the SEC was further north in the early to mid-Holocene, moving south around 6-5 ka before attaining its current position, as determined by marine ${ }^{14} \mathrm{C}$ reservoir ages of corals from islands of northern PNG (McGregor et al., 2008). Tandem analysis of $\mathrm{Sr} / \mathrm{Ca}$ and $\delta^{18} \mathrm{O}$ in corals from the GBR suggest SSTs were warmer by $\sim 1{ }^{\circ} \mathrm{C}$ around $6 \mathrm{ka}$ and SSS was higher due to increased evaporation (Gagan et al., 1998), indicating more intense El Niño conditions.

Warmer periods from 6.6 to $6.3 \mathrm{ka}$ and after $4.3 \mathrm{ka}$, are also evident in the coral records from the southern periphery of the IPWP, along with evidence for freshening after $4 \mathrm{ka}$, indicating a stronger monsoon (Gagan et al., 1998; Stott et al., 2004; Abram et al., 2009). These appear to correlate with periods of weaker Asian monsoons on the Arabian Peninsula, most likely due to a more southerly position of the ITCZ (Fleitmann et al., 2003, 2007; Wang et al., 2005). Following this, extreme and longer El Niño events are recorded between 2500 and $1700 \mathrm{ka}$ (Tudhope et al., 2001; Moy et al., 2002; Woodroffe et al., 2003; McGregor and Gagan, 2004; Gagan et al., 2004). Coral reconstructions of ENSO for the past 1100 years demonstrate the links between ENSO and changes in the mean climate of the Pacific (Cobb et al., 2003).

Coral data from the GBR show broad changes in the ocean temperature, salinity and ENSO teleconnection for the past few hundred years. Geochemical analyses $\left(\mathrm{Sr} / \mathrm{Ca}, \mathrm{U} / \mathrm{Ca}, \delta^{18} \mathrm{O}\right)$ on eight coral cores from the central GBR indicate SSTs were $0.2-0.3{ }^{\circ} \mathrm{C}$ cooler in the period 1565-1700 AD (relative to the long-term average taken from the composite set). Warmer SSTs and higher salinity persisted in the 18th Century before cooling at the end of the 19th and early 20th Centuries and warming again from the mid20th Century (Hendy et al., 2002). A distinct 'freshening' of the GBR lagoon was observed after $1870 \mathrm{AD}$, coinciding with the end of the Little Ice Age and linked to a change in atmospheric and/or ocean circulation (Hendy et al., 2002).

The intensity of luminescent lines in inner GBR Porites coral cores are directly correlated with river discharge and as such, also linked to the strength and variability of ENSO, the Pacific Decadal Oscillation and the monsoon (Hendy et al., 2003; Lough, 2007). The luminescence data dating from the early 1600's AD show variability in ENSO teleconnections over this period, extended droughts (e.g. mid 1760s to mid 1780s) and changes towards higher variability in wet and dry years ('extremes') during the 20th Century (Hendy et al., 2003; Lough, 2007).

\section{Speleothem records}

Speleothems are capable of providing continuous highresolution records of terrestrial climate spanning hundreds of thousands of years that can be absolutely dated using highprecision ${ }^{230} \mathrm{Th} /{ }^{234} \mathrm{U}$ methods (Edwards et al., 1987). Two of the most useful proxies of past rainfall changes in speleothems have proven to be oxygen isotope ratios $\left(\delta^{18} \mathrm{O}\right)$ and trace element ratios, such as $\mathrm{Mg} / \mathrm{Ca}$ and $\mathrm{Sr} / \mathrm{Ca}$ (e.g. Griffiths et al., 2010a). The $\delta^{18} \mathrm{O}$ composition of speleothem calcite deposited under isotopic equilibrium conditions is controlled by the $\delta^{18} \mathrm{O}$ of the cave drip water, which is closely related to rainfall $\delta^{18} \mathrm{O}$, and temperature (McDermott, 2004; Lachinet, 2009). In the tropics, however, the "temperature effect" is typically masked by the much larger influence of the cave drip-water $\delta^{18} \mathrm{O}$ (and hence rainfall $\delta^{18} \mathrm{O}$ ) signal (Dansgaard, 1964). Whilst controls on the isotopic composition of rainfall at a given site are extremely complex and can be quite sitespecific, numerous studies have shown speleothem $\delta^{18} \mathrm{O}$ records to be extremely useful in reconstructing variations in monsoon "intensity" (e.g. Wang et al., 2001; Wang et al., 2008; Zhang et al., 2008) and local rainfall amount (e.g. Partin et al., 2007; Griffiths et al., 2009; Lewis et al., 2011) across the southeast Asian region. The latter "amount effect" (Dansgaard, 1964), whereby lower $\delta^{18} \mathrm{O}$ values are interpreted to reflect wetter conditions and vice versa, is the most dominant on tropical oceanic islands (Dansgaard, 1964; Rozanski et al., 1992).

Key $\delta^{18} \mathrm{O}$ speleothem records from northern Borneo (Partin et al., 2007), in the centre of the ITCZ and Flores, east Indonesia (Griffiths et al., 2009, 2010a,b; Lewis et al., 2011), at the modern southern margin, document changes of monsoonal rainfall in the region since the early glacial (Fig. 5). At present, around $70 \%$ of the rainfall on Flores comes from the monsoon, whereas the low-level south-easterly trades dominate in winter (Griffiths et al., 2009). The Borneo site receives rainfall throughout the year, but is influenced by ENSO (Partin et al., 2007).

Between 31 and $26 \mathrm{ka}, \delta^{18} \mathrm{O}$ values are relatively enriched in the Flores record, although there is a high degree of variability (Lewis et al., 2011). $\delta^{18} \mathrm{O}$ values at these times of low sea levels appear to track changes in Southern Hemisphere summer insolation, with higher (drier) corresponding to lower summer insolation (Lewis et al., 2011). The $\delta^{18} \mathrm{O}$ record from Borneo for the period 27 to 20 ka shows a consistent trend although significant variability, enriched in comparison to modern values (Partin et al., 2007). A steadily increasing $\delta^{18} \mathrm{O}$ record, corresponding to a drying trend occurs from 20 to $15 \mathrm{ka}$, with the driest values corresponding to 


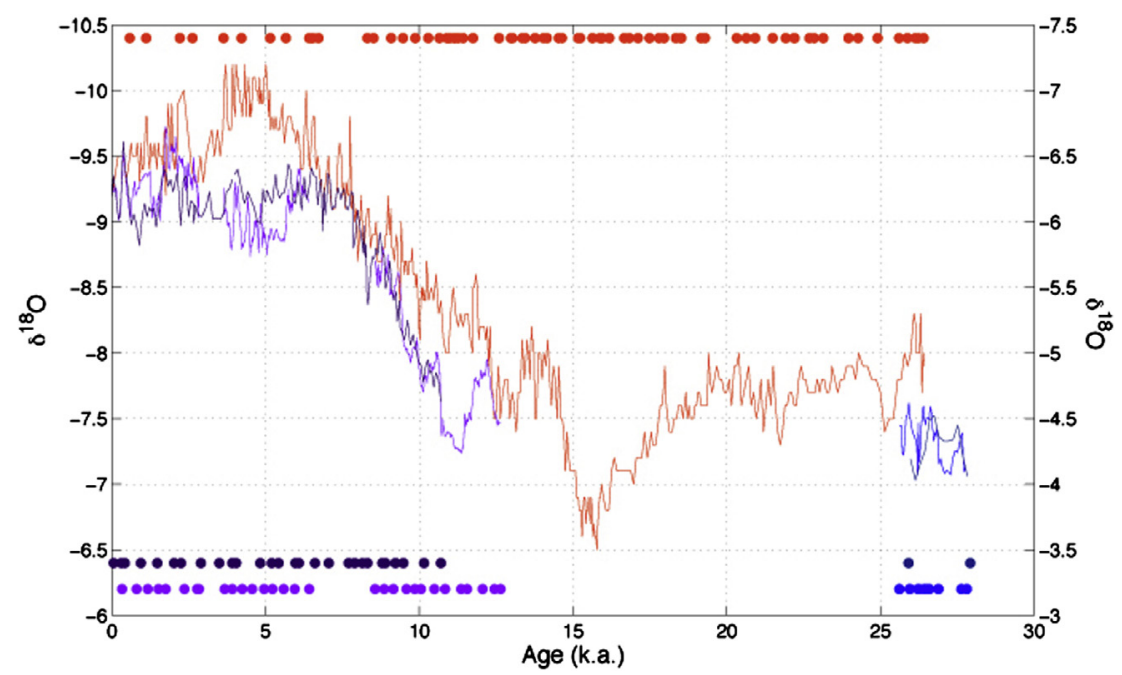

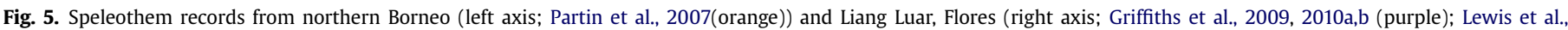
2011(blue)) showing $\delta^{18} \mathrm{O}$ as a proxy for precipitation.

Heinrich event 1 of the Northern Hemisphere, suggesting a southward movement of the ITCZ brought about by weakened Atlantic meridional overturning circulation (AMOC) (Partin et al., 2007).

A rapid decrease in $\delta^{18} \mathrm{O}$, indicating wetter conditions in Borneo occur from 15.5 to $14.7 \mathrm{ka}$, before a millennial-long plateau coincident with the ACR, centred around $13.2 \mathrm{ka}$, followed by a more gradual and persistent wetting through the early Holocene (Partin et al., 2007). The latter stages of the deglacial period at Flores $(\sim 12.6-11.6 \mathrm{ka})$ are marked by changes in $\delta^{18} \mathrm{O}$ and trace element values implying, in contrast to Borneo, wetter conditions (Griffiths et al., 2009, 2010a), and by changes in fluid inclusion $\delta^{18} \mathrm{O}$ values suggesting local cave temperature decreases of up to $5 \pm 1.5{ }^{\circ} \mathrm{C}$ compared to present (Griffiths et al., 2009, 2010b). This divergence between the records suggests another short-lived southward displacement of the ITCZ (Griffiths et al., 2009, 2010a).

After $11.6 \mathrm{ka}$, the speleothem $\delta^{18} \mathrm{O}$ records show precipitation responding to flooding of the shelf and regional ocean-atmosphere dynamics. Griffiths et al. $(2009,2013)$ suggested two possibilities for the influence of rising sea-level on the strength of the Australian monsoon, which include: (i) during the late deglacial/early Holocene, a smaller surface area of ocean water along the dominant air-mass trajectory would have either limited the availability of moisture to fuel the monsoon or greatly affected atmospheric circulation patterns; (ii) the other, somewhat complementary, possibility is that sea-level rise plus insolation-induced warming of the South China Sea may have resulted in the migration of relatively warm oceanic waters into the Sunda area via the ITF, thus resulting in higher evaporation over the monsoon source region. Strongly co-varying trace element ratios and $\delta^{18} \mathrm{O}$ values measured in speleothems suggest that the early Holocene in Flores was drier than the late Holocene, and that the mid-Holocene climate was characterized by a more positive IOD-like mean state with associated northward shifts of the ITCZ resulting in reductions in monsoon strength (Griffiths et al., 2009, 2010a,b). The antithetical response of the Borneo $\delta^{18} \mathrm{O}$ record between 6 and $4 \mathrm{ka}$ is consistent with this interpretation of changed ocean-atmosphere circulation patterns in the Australasian region (Partin et al., 2007; Griffiths et al., 2010b).

\section{Geomorphic indicators: lacustrine, fluvial, aeolian and glacial}

Hydrologic change in response to major climatic drivers of the Australasian tropical region is also recorded in geomorphic response within terrestrial sediments. Lacustrine and fluvial environments provide direct evidence for the presence/absence, and relative abundance, of water in the landscape. Past hydrological conditions can be reconstructed using a combination of lake sediment cores, lake shoreline dune height, distribution and sedimentology, bedload deposits in rivers, as well as terrace and source-bordering dune morphology and stratigraphy. Lake shorelines record time intervals of lake level and volume, during individual highstands, while faunal assemblages and carbonate geochemistry, including $\delta^{18} \mathrm{O}$ values and trace-element ratios, provide complementary information on lake hydrology, salinity and hydrochemistry.

Fluvial records, while discontinuous, unambiguously respond to major changes in flow regime, especially wetter periods, although floods may result in the destruction of deposits of earlier events through erosion and reworking of previously deposited sediments. Alluvial records yield palaeohydrologic information based on the distribution and sedimentology of bedload deposits and finer fractions in estuaries. Lower resolution reconstructions can be obtained from terraces, floodplains, palaeochannels, billabongs and waterfall plunge-pools. Close to river mouths and terminal discharge points, alluvial records are dominated by cut-and-fill deposits associated with sea (base) level rise and fall, in some places extending as far back as the early Quaternary (e.g. Nanson et al. 1993). Fluvial records further upstream and closer to the headwaters, are clearer indicators of changes in climate and flow regime.

Aeolian landforms, such as source-bordering dunes adjacent to rivers and lakes and desert dunes overlying abandoned lake floors, provide additional evidence for lacustrine transgression and regression, as well as fluvial activity. Aeolian activity may take place in response to increased availability of sediment, which in the case of source-bordering dunes, may reflect increased sediment influx under wetter conditions, followed by drying and erosion, or dune remobilisation as a response to local aridity. Coastal dunes also reflect periods of relative stability or mobilisation during arid periods largely as a function of vegetation cover and/or wind strength.

Glacial landforms, both erosional (such as ice moulded bedrock) and depositional (such as moraines), record the former presence and extent of glaciers. Tropical glaciers generally only form where temperature remains below $0{ }^{\circ} \mathrm{C}$ for long periods of the year and therefore are sensitive records of temperature (Benn et al., 2005). In the tropical Australian region, the glaciers of the PNG highlands are the most significant. 


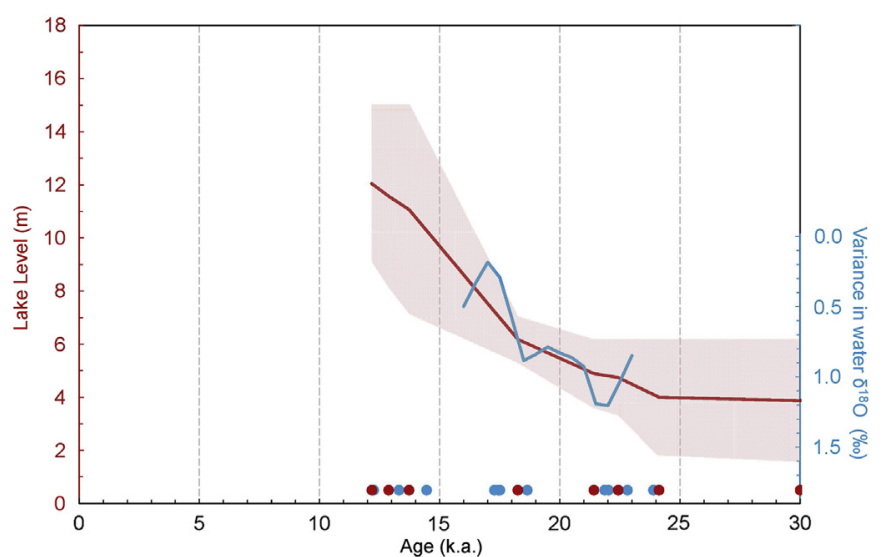

Fig. 6. Lake level of Lake Carpentaria, estimated from the depths of the sedimentological intervals in the cores and the relative depth of the cores (Devriendt, 2011). The blue line shows a 2000 year running variance in $\delta^{18} \mathrm{O}$ with steps of 500 years.

\subsection{Lakes}

Lake Carpentaria, located on the landbridge formed by lowered sea level between Australia and PNG, was a permanent feature between 44 and $12 \mathrm{ka}$ following subaerial exposure of the basin (Fig. 6) (Torgersen et al., 1988; Reeves et al., 2008). During the LGM, a permanent lake covered an area $>30,000 \mathrm{~km}^{2}$ with a mean water depth of $>2 \mathrm{~m}$, in contrast to the complete dessication witnessed during MIS 4 (Reeves et al., 2008). During this time period, large fluctuations of the lake level at the seasonal and/or interannual time scale are inferred from the $\delta^{18} \mathrm{O}$ values and trace-element ratios of ostracod shells (Devriendt, 2011). Sedimentological evidence suggests a significant increase in lake level and extent after 18 ka (Reeves et al., 2008) This is confirmed by freshening of the lake and a considerable decrease in the lake water $\delta^{18} \mathrm{O}$ variability after 18 ka (Reeves et al., 2007; Devriendt, 2011). The maximum lake level ( $>3 \mathrm{~m}$ average depth) and extent $\left(>100,000 \mathrm{~km}^{2}\right)$, as well as the lowest salinity, are recorded between 14 and $12 \mathrm{ka}$, suggesting the monsoon reached northeastern Australia around this time (Reeves et al., 2007, 2008). From $\sim 12 \mathrm{ka}$, oceanic waters transgressed the Arafura Sill, and by $10.7 \mathrm{ka}$, the Lake Carpentaria region had become marine (De Deckker et al., 1988; McCulloch et al., 1989; Chivas et al., 2001).

The Gregory Lakes basin, a series of terminal freshwater lakes on the semi-arid, northern margins of the Great Sandy Desert in northwestern Australia, is located towards the southern margins of the monsoon-affected region. The lakes are fed by monsooninfluenced streams, with the level of fluvial activity and lake level fluctuations responding to palaeomonsoon intensity, resulting in an archive of interdigitating fluvial and lacustrine sediments reflecting palaeomonsoon variability (Bowler et al., 2001; Veth et al., 2009). Following very high lake levels which fell around $\sim 37$ ka (Veth et al., 2009), intermittent desert dune formation in the Gregory Lakes catchment persisted to $\sim 11.5 \mathrm{ka}$, suggesting relatively dry conditions up until that time, after which lake levels rose again (Fitzsimmons et al., 2012). Lacustrine and fluvial deposits within the basin suggest increasing flow associated with higher precipitation related to monsoon reintensification from $\sim 14 \mathrm{ka}$ (Wyrwoll and Miller, 2001). Although lake levels in the Gregory Lakes basin rose during the early Holocene following the rejuvenated monsoon (Wyrwoll and Miller, 2001), they did not reach those of the MIS 5e interglacial at any time during the last $\sim 50 \mathrm{kyr}$ (Fitzsimmons et al., 2012).

\subsection{Rivers}

Luminescence dating (OSL and TL) of fluvial sediments has provided useful chronological constraints on palaeoenvironmental change in three areas of tropical Australia: 1) plunge pools associated with sandstone escarpments within $\sim 250 \mathrm{~km}$ of Darwin (Nott and Price, 1994, 1999; Nott et al., 1996), 2) the Gilbert River on the Gulf of Carpentaria (Nanson et al., 1991, 2005; Jones et al., 2003), and 3) the Fitzroy River of north-east Queensland (Croke et al., 2010) (Fig. 1A). At each of these sites the presence of significant bedload deposits is taken to be an indicator of strong fluvial activity, consistent with a well-established methodology (Lewin et al., 2005). Sites that are thought to reflect eustatic adjustments (e.g. Wasson, 1992; Nanson et al., 1993; Ward et al., 2005), or uncertain dating control (Thomas et al., 2001) have been excluded from analysis in this review.

In several bedrock rivers draining sandstone escarpments, large, active plunge pools have preserved coarse sediment deposits on high levées akin to 'beach ridges' activated by high-magnitude floods (Nott and Price, 1994, 1999; Nott et al., 1996). These TLdated deposits have been interpreted to indicate runoff was greatly enhanced in the period from about 30 to $17 \mathrm{ka}$, although it is unclear whether these were episodic high-magnitude events or a relatively continuous period of increased flood activity (Nott and Price, 1994). Indeed these features may also have been reworked by aeolian activity. The plunge pools reveal a more clearly defined period of enhanced flows that occurred in the early to midHolocene between about 8 and $4 \mathrm{ka}$, ceasing in the late Holocene. The Gilbert River alluvial fan on the Gulf of Carpentaria hosts a suite of distributary palaeochannels dated using TL (Nanson et al., 1991, 2005) and suggest increased fluvial activity around $30 \mathrm{ka}$ (Nanson et al., 2005, Fig. 6), rather than during the LGM. In agreement with the plunge pools, enhanced flows in the Gilbert River were reestablished in the early to mid-Holocene.

The Fitzroy River catchment in northeast Queensland is the second largest exoreic river in Australia and the main drainage into the GBR lagoon. Based on drilling and OSL-dating of thick bedload sequences across four subcatchments, Croke et al. (2010) interpreted several discrete and non-synchronous phases of fluvial activity. Increased fluvial activity took place from about 30 to $10 \mathrm{ka}$, with valley floors accumulating thick bedload sheets throughout the LGM. There is a remarkable lack of evidence for Holocene activity in this system.

A summary of phases of enhanced fluvial activity based on frequency analysis of dated bedload units in tropical rivers (Fig. 7) builds on an earlier version reported in Nanson et al. (2008). Pronounced fluvial activity recorded before $40 \mathrm{ka}$, is followed by an abrupt decline from $\sim 40$ to $\sim 30 \mathrm{ka}$ and then a gradual increase in fluvial activity, peaking from $\sim 12$ ka through to the mid Holocene.

\subsection{Aeolian landforms}

Desert dunes extend into the monsoon-influenced plains of central northern and northwestern Australia (Hesse, 2010); however chronologic records of the timing of activity are limited to small-scale studies in the northwest responding either to local aridity or hydrology, and to coastal dunes which more closely reflect sea level change.

Within the Gregory Lakes catchment, desert dune formation persisted throughout the period $\sim 35-11.5 \mathrm{ka}$, and most likely indicates lake regression and relatively arid conditions in response to a monsoon system which was either inactive or did not penetrate this far south into the interior (Fitzsimmons et al., 2012). The monsoon reactivated from $\sim 14 \mathrm{ka}$ (Wyrwoll and Miller, 2001), as evidenced by lacustrine deposition in the catchment. It is therefore 

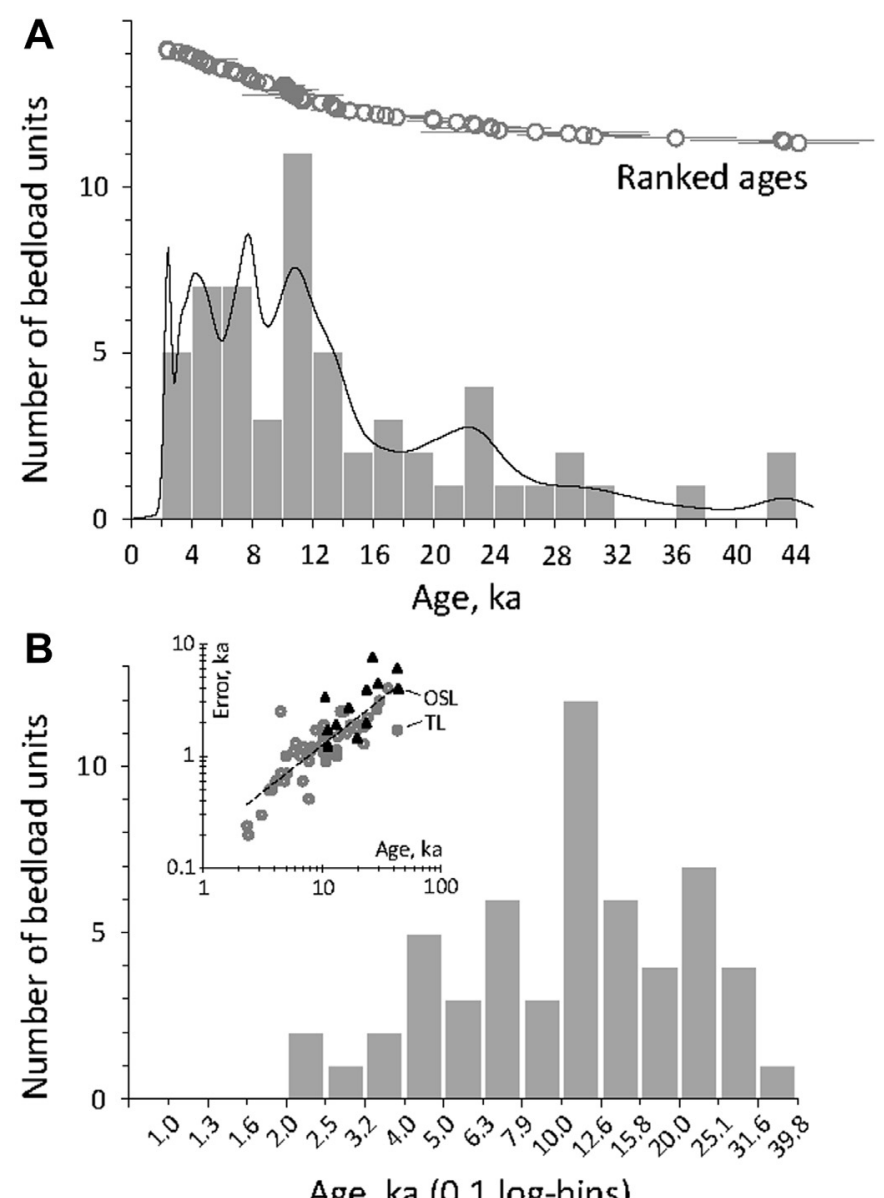

Fig. 7. Compilation of OSL and TL dated bedload units from rivers in northern Australia plotted as frequency distributions of depositional ages since $42 \mathrm{ka}(n=56)$. OSL and TL ages derived from Nanson et al. (1991, 2005), Nanson, unpublished, Nott and Price (1994, 1999), Nott et al. (1996), Jones et al. (2003) and Croke et al. (2010). Ages $<2$ ka are excluded, and the weighted mean age is plotted for bedload units with multiple dates. A) Ranked age plot with $1 \sigma$ errors, histogram (linear 2 ka bins), and kernel density estimate ( $0.1 \mathrm{ka}$ bandwidth). B) The same data separated into $0.1 \mathrm{log}$ arithmic bins, which expand with age as indicated. Inset plot: $1 \sigma$ errors versus age showing fairly consistent error scaling among OSL and TL ages (error $=0.18$ age $^{0.83}$, $\left.r^{2}=0.68\right)$

feasible that aeolian activity during the deglacial period was related to increased local sediment supply, rather than to arid conditions (Fitzsimmons et al., 2012).

Wende et al. (1998) describe an isolated aeolian dune adjacent to an alluvial plain in the eastern Kimberley region of Western Australia, which was active both during the LGM and in the late Holocene following decline in fluvial activity in a nearby river. During the mid-Holocene ( $\sim 5 \mathrm{ka})$, substantial dune re-activation took place in the Gregory Lakes catchment. The most likely explanation for this is the onset of a short-lived, intense arid phase in northwestern Australia (Fitzsimmons et al., 2012).

In northern Australia, the siliceous coastal dunefields were largely sourced from fluvial deltas exposed during times of low sea level (Lees and Lu, 1991, 1992). The most well-dated sequence from Cape York Peninsula reveals dune emplacement at $\sim 29$ ka and 24$18 \mathrm{ka}$, dated by TL methods (Lees et al., 1990; Lees, 1992), corresponding to fluctuating lake levels in Carpentaria and plunge pool activity. A number of sites reveal a cluster of ages around the midHolocene, which may be in response to a combination of sea-level stabilisation and changing climatic conditions (Lees, 2006). Other recognised dune 'events' include 3.4-2.9 ka in the Kimberley dune field and active coastal dune transgression in many sites in the last 2 ka (Lees, 2006), which may relate to increased climate variability and intensification of human activity (Williams et al., 2010). Although the overall pattern of dune activation in northern Australia shows some consistent patterns, the wide margins of error on the dating of the dunes preclude more precise interpretation.

\subsection{Glacial geomorphology}

In comparison to hydrological landforms in this region, glacial landforms are highly restricted to only the most mountainous environments. Apart from small glaciers in Indonesia and Malaysia, most glaciation of the western Pacific Tropics was on the island of New Guinea. The total maximum extent covered by ice is likely to be of the order of $3400 \mathrm{~km}^{2}$ (Prentice et al., 2005, 2011). Dating of the timing of glaciation in this part of the Tropics has historically been poor. Limited radiocarbon ages date the last glaciation over a broad period from 28 to $17 \mathrm{ka}$ (Prentice et al., 2011). Mt Wilhelm has the best radiocarbon dated retreat sequence demonstrating that deglaciation was initiated before $14.8 \mathrm{ka}$ and the mountain was ice free by 9.3 ka with no major re-advances of ice (Hope and Peterson, 1975).

Moraines on the extinct volcano of Mt Giluwe, PNG have been directly dated using exposure dating (Barrows et al., 2011) providing the most detailed record of ice advance in the western Pacific Ocean tropics. Ice was at its maximum extent around 19.4-20.3 ka and was in retreat by $18.3 \mathrm{ka}$. The maximum temperature difference relative to the present during the LGM is likely to be more than $5{ }^{\circ} \mathrm{C}$. Retreat of ice appears to have been slower to $15.4 \mathrm{ka}$ than subsequently, with no major re-advance of ice during the deglaciation (Barrows et al., 2011). Ice retreated during the YD chronozone and disappeared from the highest altitudes around $11.5 \mathrm{ka}$ (Barrows et al., 2011). The pattern of deglaciation closely follows records of vegetation change from Mt Wilhelm (Hope, 1976).

\section{Pollen and charcoal}

Pollen and charcoal records provide an important evidence for changes in vegetation, biomass and fire regimes in the region, due to both local and more regional effects, spanning the last $30 \mathrm{ka}$. This information can be used to provide a continuous reconstruction of past terrestrial climates that can be compared and contrasted with the other environmental records from the region. The key pollen records from Rawa Danau, Java, the Banda Sea and offshore Queensland, adjacent to the GBR are presented in Fig. 8, along with a composite of charcoal records from within the region.

While the most detailed palaeoecological research in the tropics of Australia has been focussed on the Atherton Tableland region, recent efforts to explore the potential of uncovering records spanning the last $30 \mathrm{ka}$ or more in other regions across northern Australia are beginning to yield positive outcomes. Sediment cores from palaeochannels on the Mitchell Plateau in the Kimberley region or northwestern Australia have returned radiocarbon dates spanning the last $30 \mathrm{kyr}$ and have shown the potential to preserve pollen over this timeframe (Haberle et al., 2011). Other recent research in the seasonally dry tropics of the northeast has shown potential for records extending back to at least the Holocene (e.g. Prebble et al., 2005; Luly et al., 2006; Rowe, 2007).

The early glacial period sees effective precipitation similar to present and cooler conditions in northern Sumatra (van der Kaars et al., 2012), at Danau di Atas in the highlands of Sumatra (Newsome and Flenley, 1988) and Lake Hordorli in Papua (Hope and Tulip, 1994), but much drier in Rawa Danau, a lowland swamp in Java, and southwest Sumatra (van der Kaars et al., 2001, 2010) and Cape Range (van der Kaars and De Deckker, 2002; van der Kaars 


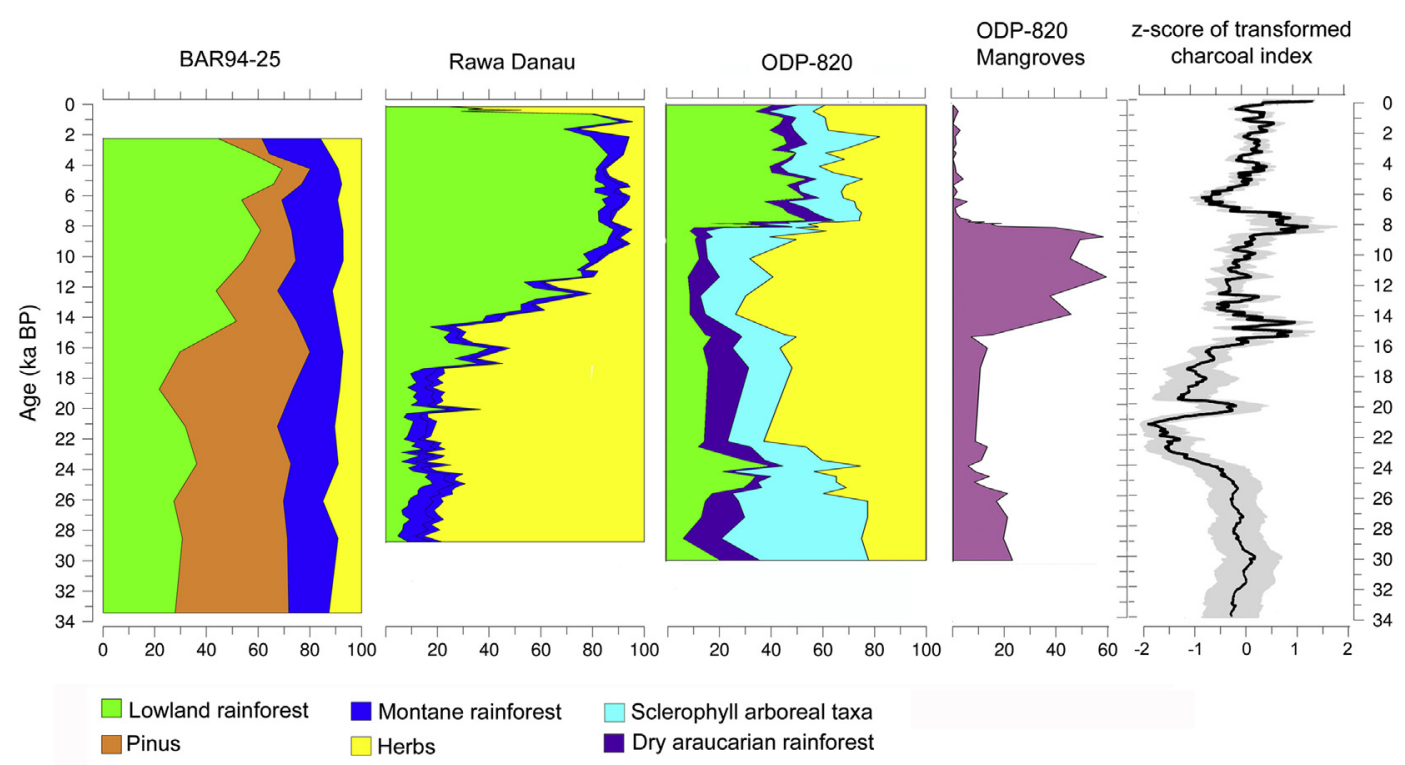

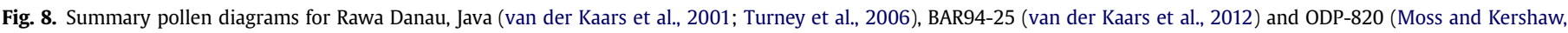
2007) and the composite charcoal record from tropical Australasia (Mooney et al., 2011).

et al., 2006). Sirunki in the highlands of PNG shows much cooler conditions during the Last Glacial period (Walker and Flenley, 1979). Forest collapse is noted in several records across the island (e.g. Haberle, 1998; Hope, 2009). The north-eastern Queensland records (Lynch's Crater; Lake Euramoo) show cooler, dry, open woodlands right through the glacial period (Kershaw, 1976; Turney et al., 2004; Haberle, 2005; Kershaw et al., 2007; Moss and Kershaw, 2007). In addition, the ODP 820 record, offshore of Cairns, shows a peak in mangrove pollen at 30-26.5 ka, which then declines during the LGM and may reflect increased soil erosion associated with anthropogenic activity in addition to falling sea-level (Grindrod et al., 1999, 2002; Moss and Kershaw, 2000, 2007). The vegetation at Danau di Atas, Sumatra responds strongly to the full glacial, with a switch from montane rainforest to shrubs between 21.1 and $20.2 \mathrm{ka}$, corresponding to a temperature decrease of as much as $7{ }^{\circ} \mathrm{C}$ (Newsome and Flenley, 1988). Temperature estimates for the LGM range from $\sim 3$ to $4{ }^{\circ} \mathrm{C}$ cooler than present, with increased high altitude taxa at Lake Hordorli (Hope and Tulip, 1994) to as much as $9-11^{\circ} \mathrm{C}$ cooler in the PNG highlands with forest replaced by alpine herbs and grasses (Walker and Flenley, 1979). However, it should be noted that with no true modern analogue for the glacial assemblages, these estimations should be treated with caution (e.g. Hope, 1989).

The vegetation response during the deglacial period varies across the region. In northern Sumatra, an increase in lowland rainforest indicates the onset of warmer conditions from $\sim 16 \mathrm{ka}$ (van der Kaars et al., 2012). Gymnosperms increase from $20.2 \mathrm{ka}$, signifying much cooler conditions at Danau di Atas, which persisted until $\sim 15 \mathrm{ka}$ (Newsome and Flenley, 1988; Williams et al., 2009). At Rawa Danau, there was an initial increase in lowland forest, indicating higher temperatures and to a lesser degree higher precipitation from $17 \mathrm{ka}$, although 15.4-14.6 ka saw a decrease in forest and increase in grasses (van der Kaars et al., 2001; Turney et al., 2004). Warmer and wetter conditions are also noted from southwest Sumatra from $17 \mathrm{ka}$ (van der Kaars et al., 2010). Recovery of the lower montane forest in highland PNG, with greatest warming, took place 19.1-15.7 ka (Walker and Flenley, 1979; Williams et al., 2009). A return of summer precipitation is noted at Cape Range from $20.4 \mathrm{ka}$, with slightly higher temperatures (van der Kaars and De Deckker, 2002; van der Kaars et al., 2006). Although wetter conditions with Eucalyptus woodland are recorded from Lake Euramoo from 16.8 to 12.6 ka (Haberle, 2005), Lynch's Crater and the ODP 820 records suggest dry conditions (Kershaw, 1976, 1981; Peerdeman et al., 1993; Moss and Kershaw, 2000, 2007; Turney et al., 2004; Kershaw et al., 2007). Anthropogenic influence, by clearing and burning, has been inferred for this lag in response, although it may also reflect the time taken for rainforest to expand from refugia occupied during the Last Glacial period after climate change (Moss and Kershaw, 2007). The closer proximity of Lake Euramoo to these refugia would have allowed a quicker recolonisation under favourable conditions. The composite charcoal record shows a peak at around $15 \mathrm{ka}$, perhaps indicating an increase in available woody fuel (Mooney et al., 2011). The ODP 820 record shows an increase in mangroves at $15 \mathrm{ka}$, which then peaks at $9 \mathrm{ka}$ and represents the flooding of the continental shelf and associated 'big swamp phase' as sea levels increase during the deglaciation and early Holocene (Woodroffe et al., 1985; Grindrod et al., 1999, 2002).

Modern vegetation patterns are established first on northern Sumatra by $\sim 14$ ka (van der Kaars et al., 2012), Cape Range by 14.2 ka (van der Kaars and De Deckker, 2002) and a little later (12.3 ka) in Papua (Hope and Tulip, 1994), southwest Sumatra from 11.9 ka (van der Kaars et al., 2010) and Java 11 ka (van der Kaars et al., 2001; Turney et al., 2006). After a brief wet period at Lynch's Crater (12.6-11.6 ka) (Turney et al., 2004), dry conditions occur at both Lynch's Crater and Lake Euramoo (Turney et al., 2004; Haberle, 2005), with rainforest established at $10.9 \mathrm{ka}$ and $9.6 \mathrm{ka}$, respectively. This is also reflected at the regional scale in the ODP 820 record, in which the expansion of rainforest is inferred at around $9 \mathrm{ka}$. In addition, mangroves decline markedly in the ODP 820 record from $8.5 \mathrm{ka}$ and represent the effects of Holocene high sea-levels increasing the distance between the ODP 820 site and mangrove pollen sources, as well as a decline in mangrove habitat due to the lack of a relatively flat topography (Grindrod et al., 1999, 2002). Both Danau di Atas and Sirunki sites also show the modern vegetation assemblage appearing by the early Holocene (Walker and Flenley, 1979; Newsome and Flenley, 1988). A second peak in the composite charcoal record occurred around $8 \mathrm{ka}$ (Mooney et al., 2011). The Banda Sea records, including pollen and coccoliths, show a significant shift in the position of the monsoon around $6 \mathrm{ka}$, suggesting low-latitude insolation forcing (Beaufort et al., 2010). An 
increase in variability in the Late Holocene pollen records from around the Gulf of Carpentaria (Shulmeister and Lees, 1995; Prebble et al., 2005; Luly et al., 2006; Rowe, 2007) and the northeastern Australian wet tropics (Haberle, 2005; Moss et al., 2012) have been attributed to increased seasonality due to ENSO.

\section{Synthesis}

A summary of the palaeoenvironmental implications of the tropical Australasian region over the last $30 \mathrm{ka}$ is presented in Table 2 , by proxy and through time. The key time intervals that have been identified in the records include the period leading up to and including the Last Glacial Maximum (30-18 ka), the deglacial period (18-12 ka), the early Holocene (12-8 ka) and the mid to late Holocene $(8-0 \mathrm{ka})$. The varying responses through time are represented by diagrams in Fig. 9.

Relatively cool and wet conditions are characteristic of the northern Australian region and northern Indonesia, seen in the pollen, lake, fluvial and speleothem records of late MIS 3 (Fig. 9A). Pollen records of southern Indonesia, however, indicate an onset of drying during this time. The early glacial period in the Borneo speleothem, Lake Carpentaria and northeast Queensland pollen records shows a relatively constant trend in moisture availability, but with increasing variability. This infers that the ITCZ moved considerably north during late MIS 3 , then gradually shifted southward around 28-24 ka. However, this migration was insufficient to invoke an intensified monsoon on mainland Australia.

Conditions during the Last Glacial Maximum are universally cooler - although to varying degrees (Fig. 9B). Glacial records are in good agreement with deep sea records of the timing of maximum cooling at $\sim 20 \mathrm{ka}$. Revised evidence from the PNG glacier reiterates a large temperature change at high altitude of $>5^{\circ} \mathrm{C}$, supported by similar estimates from vegetation change. However, at the sea surface there is only cooling of the order of $0-3{ }^{\circ} \mathrm{C}$ derived from a rigorous compilation of SST estimation techniques (MARGO Project Members, 2009). The cooling is the most evident outside the contracted IPWP and south of the Coral Sea. A climatological explanation remains to be found.

Pollen records reveal universally drier conditions, in conjunction with cooler temperatures for much of the lowland regions of tropical Australasia during the LGM. In parts of Sumatra, Borneo and lowland New Guinea, and particularly in the montane regions of Indonesia, cooler conditions during the glacial period are also apparent. However, unambiguous evidence for drier glacial conditions is missing. Geomorphic records reveal the LGM was characterised by episodic and sometimes extreme rainfall events, seen in the plunge pool and fluvial records of northern Australia, but with dry conditions northwestern Australia and south of the Gulf of Carpentaria. The monsoon is considered to be inactive, or greatly weakened at this time.

During the deglacial period, warmer conditions occurred on both land and sea, coupled with a re-organisation of the ITF and flooding of the Sunda shelf (Fig. 9C). This initially brought greater precipitation in Indonesia, then in northern Australia, with the expansion and intensification of the monsoon, due to the southward migration of the ITCZ. Deglacial warming in the PNG highlands commenced immediately after the LGM, becoming more rapid after $15.4 \mathrm{ka}$. Warming is also evident in the marine records as early as $20 \mathrm{ka}$ in the Coral Sea. Although the decline in ice volume corrected $\delta^{18} \mathrm{O}$, due to both increased temperature and decreased salinity, occurred rapidly during $18-15 \mathrm{ka}$ in the east, it lagged in the seas to the northwest of Australia, where is commenced around $15 \mathrm{ka}$. Drying conditions in Borneo are mirrored by an expansion of Lake Carpentaria and wetter and warmer conditions in southern Indonesia from early in the deglacial period.

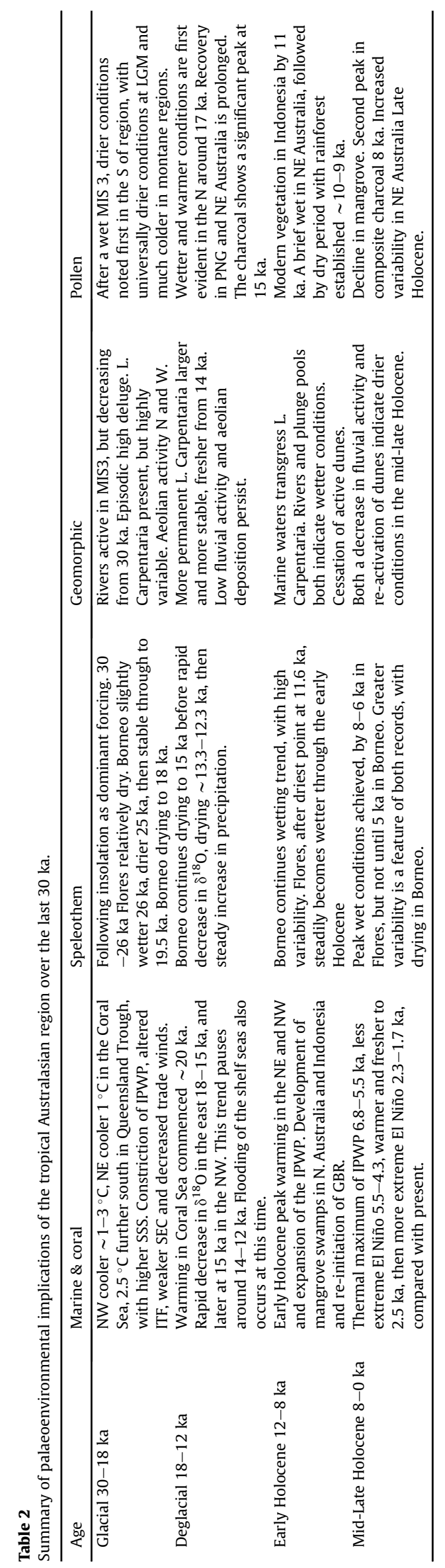


A

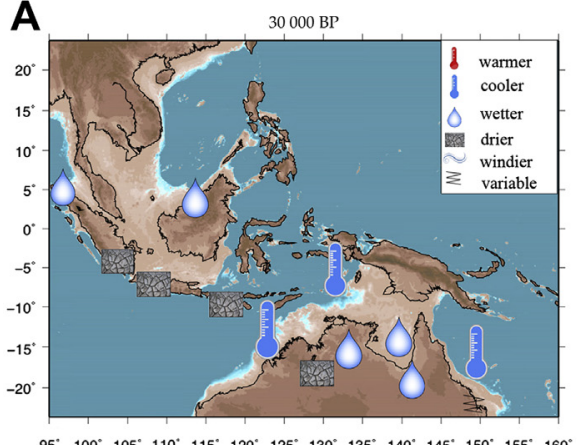

D

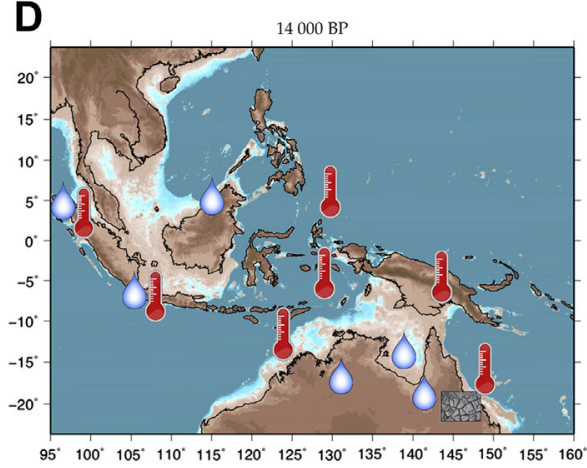

B

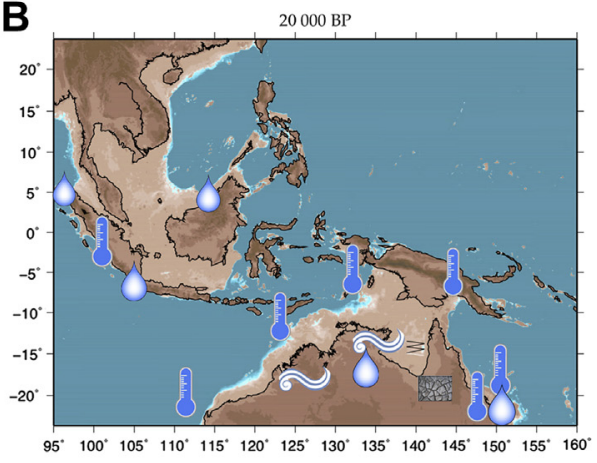

E

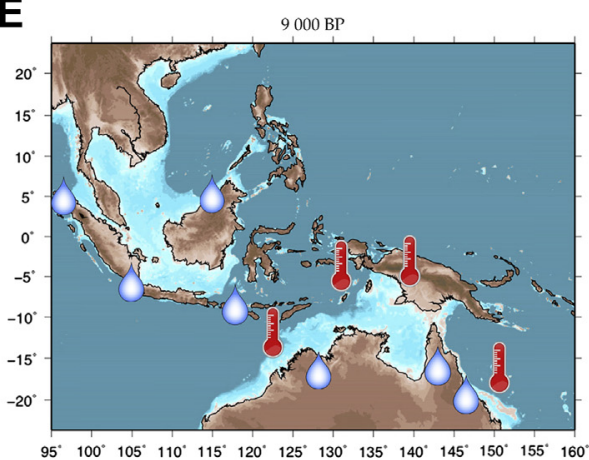

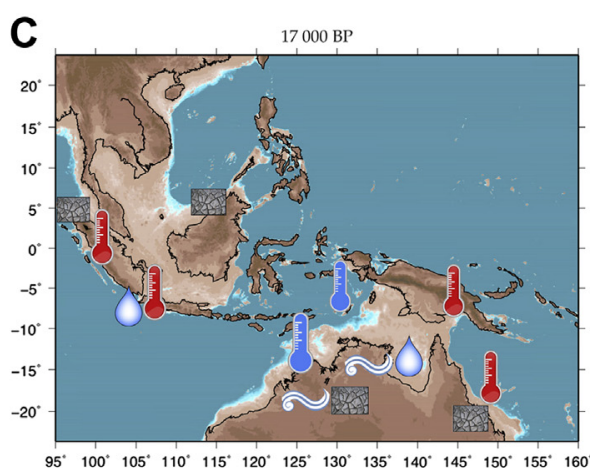

$\mathbf{F}$

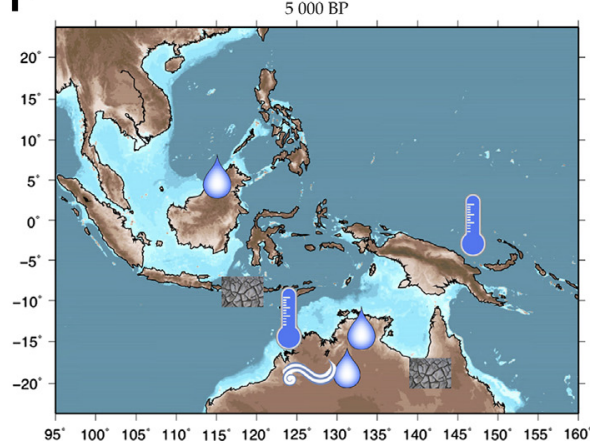

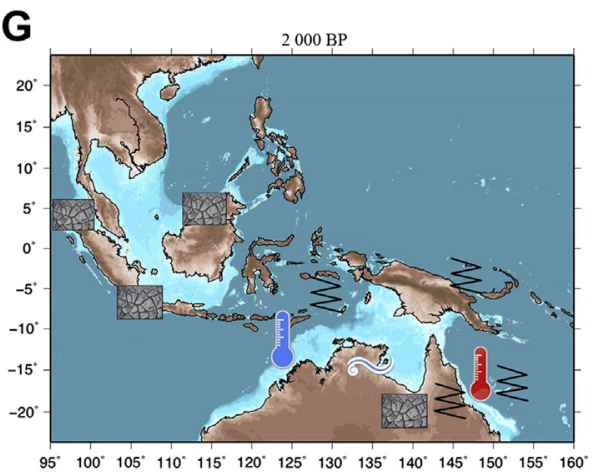

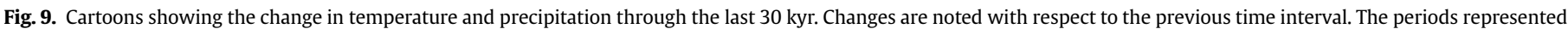
here are A) $30 \mathrm{ka}$, B) $20 \mathrm{ka}$, C) $17 \mathrm{ka}$, D) $14 \mathrm{ka}$, E) $9 \mathrm{ka}$ and F) $5 \mathrm{ka}$ and G) $2 \mathrm{ka}$.

During the late deglacial period, marine records show $\delta^{18} \mathrm{O}$ varied little across the region around the timing of the ACR, although there is some evidence of minor cooling and/or drying at the extremities of the IPWP (Fig. 9D). SST again rose dramatically at the end of the deglacial period, associated with peak flooding of the continental shelf, re-initiation of coral reef growth and the development of large estuarine systems. A rapid increase in precipitation is evident in Borneo commencing $\sim 15 \mathrm{ka}$, with a brief hiatus around the ACR. Modern vegetation was largely established in Indonesia during this time.

There is a divergence in estimates of climate within the YD chronozone between coral palaeothermometers (cooling) and other SST techniques/terrestrial evidence (warming). Some of the discrepancies in temperature estimates derived from different marine organisms may be calibration specific and/or due to additional climate factors, such as influence of surface winds (Leduc et al., 2010; Gagan et al., 2012). However, cooling during the YD chronozone is apparent in deep sea records from the low latitudes of the Northern Hemisphere and further north (Linsley and Thunell, 1990). In most records presented in this synthesis, climate shifts during the YD chronozone are not evident.
Warmer and wetter conditions were established across the region as sea-level peaked and trade winds re-invigorated in the early Holocene (Fig. 9E). This is evident in all of the proxy records, with peak wet conditions in Flores 8-6 ka, modern vegetation establishment in northeast Queensland and peak charcoal by $8 \mathrm{ka}$ and the thermal maximum of the IPWP $6.8-5.5 \mathrm{ka}$. The monsoon was clearly at its peak through this time and the ITCZ in a southward position.

A drying trend is noted in several of the records in the midHolocene, including pollen in the Carpentaria region and speleothems of Flores, coincident with increased precipitation in Borneo (Fig. 9F). A contraction of the IPWP is also recorded in the corals of this region. This implies a northward contraction of the ITCZ at this time or a more El Niño-dominated system.

Increasingly variable conditions and localised aridity are characteristic of the late Holocene (Fig. 9E). This is noted in temperature records from corals, dune records from both lake and coastal sites of northern Australia and pollen records from the Carpentaria region of northeast Queensland. This enhanced variability has a close association with ENSO, although the role of intensified human occupation on vegetation should be further considered. 
The dominant climatic feature of the Australian tropics over the last $30 \mathrm{ka}$ is the varying intensity of the monsoon. Modelling investigations using the fully-coupled low-resolution climate system model FOAM (Fast Ocean Atmosphere Model) have demonstrated the influence of insolation over the intensity, timing and penetration of the monsoon at 35, 21, 11, 6 and 0 ka (Marshall and Lynch, 2006, 2008). Previous studies using FOAM demonstrate that the initiation of the monsoon is brought about by a heat low off the west coast of Australia coincident with divergent outflow from Asia and cyclonic flow (Liu et al., 2004). This pressure differential brings about a push from the north, dominant at 11 and $35 \mathrm{ka}$ and a pull from the south at $6 \mathrm{ka}$ (Marshall and Lynch, 2006). This scenario collapses during the LGM due to cooler terrestrial temperatures and SST, and greater landmass (e.g. Miller et al., 1997). Further modelling experiments using FOAM have indicated that the onset of the monsoon is largely determined by insolation and sea level. The southward extent is controlled primarily by insolation, with increased insolation over the monsoon region bringing about a southward shift of the ITCZ, and the timing by sea level (Marshall and Lynch, 2008). The influence of surface roughness and greenhouse gas radiative forcing on the monsoon, using this model, account for less than $10 \%$ of the variation for any parameter considered (Marshall and Lynch, 2008).

The proxy data presented above largely support the outcomes of the FOAM model. The influence of the Northern Hemisphere is felt in the differential in insolation across the ITCZ controlling its movement and resultant variation in monsoon intensity, particularly at the extremities. The effect of changes in landmass/ocean, particularly across the Sunda shelf also had a strong influence on moisture availability in the region. Both the ocean temperatures affecting the amount of available moisture, as well as proximity of the terrestrial sites to the coast tend to control the proxy response to local and regional climate. Finally, changes in greenhouse gas concentrations over the glacial cycle act to synchronise temperature changes between the tropical records documented here and elsewhere in the world (Barrows et al., 2011).

\section{Future research}

This synthesis represents the current state of knowledge of palaeoenvironmental change over the past 30,000 years in the tropical Australasian region. Comparisons with the adjacent temperate (Petherick et al., 2013) and arid (Fitzsimmons et al., 2013) regions have been brought together in the Australian composite paper, also in this volume (Reeves et al., 2013). In making this compilation, we have identified both significant gaps in the current tropical dataset and potential avenues for future research.

Whilst the marine realm has been fairly well represented in this region, a significant number of the records have utilised only one proxy, such as for temperature, with inherent deficiencies. A combination of proxies (foraminifer $\delta^{18} \mathrm{O}$ and $\mathrm{Mg} / \mathrm{Ca}, \mathrm{TEX}^{86}$ ) can determine a lot more accurate and detailed information regarding SST and SSS, which is particularly valuable, given the continuous nature of most marine records. Apparent temperature paradoxes persist in the western Pacific Ocean tropics, which need to be addressed through further cross comparison studies.

Tropical speleothems represent new climate proxy records for the region and show a lot of promise. However, to date, only a handful of records have been generated for the entire Australasian region for the past $30 \mathrm{ka}$ (Partin et al., 2007; Griffiths et al., 2009, 2010a,b; Lewis et al., 2011). Considering the importance that such records have demonstrated in other tropical locations throughout the world (e.g. Wang et al., 2001; Cruz et al., 2005) these would seem obvious targets for future research of climate change in the Australasian tropics. Similarly tropical corals offer the prospect to capture the seasonal-scale climate response to glacial and deglacial period climate forcing, and to integrate these with speleothem and marine sediment core proxies (e.g. Expedition 325 Scientists, 2011).

The geomorphic archives of northern Australia, East Timor and eastern Indonesia remain largely unstudied. There are several suitable lakes and associated dunefields with the potential to elucidate hydrologic histories, as well as to compare desert dune activity in the monsoon-influenced region with that influenced by the westerlies further south. Particular target areas include the Barkly Tablelands, Kakadu wetlands and further work in the Gregory catchment. The application of exposure dating has to date been limited but holds considerable promise for putting better age constraints on past snowline variations and therefore temperature. In addition, fluvial records from Indonesia and New Guinea have received very little attention to date. These may either be examined onshore, or using deep-sea cores offshore to investigate terrigeneous clays to determine river provenance and discharge.

Most pollen and charcoal records have focussed on wetter parts of the region that contain extensive lakes and swamps or from the marine realm, in association with the marine environmental proxies. However, there is a pressing need to extend into the drier parts of Australasia, particularly the Australian savannah that characterises much of the tropical environments of this area. In addition, there is strong potential to examine records further south in eastern Australia towards the Tropic of Capricorn, where there appears to be a number of suitable lake and swamp sites that remain unstudied, and which can be compared to vertebrate records that have recently emerged from this region (Hocknull et al., 2007).

After comparison with the other regions of Australia (e.g. Reeves et al., 2013), there is an imperative to correlate the climatic fluctuations of Australasia further afield, firstly with changes evident in the ice core records of Antarctica, then throughout the Southern Hemisphere. This will be a key focus for the next phase of the project. Ultimately, the goal of INTIMATE internationally, is to bring the hemispheres together to determine leads and lags and in particular, to elucidate the role and response of the southern tropics in global climate change.

\section{Acknowledgements}

The authors gratefully acknowledge the financial support of INQUA and AINSE. This work is a contribution to INQUA PALCOMM project \#0806: Australasian-INTIMATE. This manuscript has been substantially improved by the comments of Jamie Shulmeister, Geoff Hope and Brent Alloway.

\section{References}

Abbey, E., Webster, J.M., Beaman, R.J., 2011. Geomorphology of submerged reefs on the shelf edge of the Great Barrier Reef: the influence of oscillating Pleistocene sea levels. Marine Geology 288, 61-78.

Abram, N.J., McGregor, H.V., Gagan, M.K., Hantoro, W.S., Suwargadi, B.W., 2009. Oscillations in the southern extent of the Indo-Pacific Warm Pool during the mid-Holocene. Quaternary Science Reviews 28, 2794-2803.

Anderson, D.M., Prell, W.L., Barratt, N.J., 1989. Estimates of sea surface temperature in the Coral Sea at the Last Glacial Maximum. Paleoceanography 4, 615-627.

Asami, R., Felis, T., Deschamps, P., Hanawa, K., Iryu, Y., Bard, E., Durand, N., Murayama, M., 2009. Evidence for tropical South Pacific climate change during the Younger Dryas and the Bølling-Allerød from geochemical records of fossil Tahiti corals. Earth Planetary Science Letters 288, 96-107.

Bard, E., Hamelin, B., Delanghe-Sabatier, D., 2010. Deglacial meltwater pulse 1B and Younger Dryas sea levels revisited with boreholes at Tahiti. Science 327, 12351237.

Barmawidjaja, B.M., Rohling, E.J., van der Kaars, W.A., Vergnaud Grazzini, C., Zachariasse, W.J., 1993. Glacial conditions of the northern Molucca Sea region (Indonesia). Palaeogeography, Palaeoclimatology, Palaeoecology 101, 147-167.

Barrows, T.T., Juggins, S., 2005. Sea-surface temperatures around the Australian margin and Indian Ocean during the Last Glacial Maximum. Quaternary Science Reviews 24, 1017-1047. 
Barrows, T.T., Hope, G.S., Prentice, M.L., Fifield, L.K., Tims, S.G., 2011. Late Pleistocene glaciation of the Mt Giluwe volcano, Papua New Guinea. Quaternary Science Reviews 30, 2676-2689.

Beaufort, L., van der Kaars, S., Bassinot, F.C., Moron, V., 2010. Past dynamics of the Australian monsoon: precession, phase and links to the global monsoon concept. Climate of the Past, 695-706.

Beck, J.W., Edwards, R.L., Ito, E., Taylor, F.W., Recy, J., Rougerie, F., Joannot, P., Henin, C., 1992. Sea-surface temperature from coral skeletal strontium/calcium ratios. Science 257, 644-647.

Beck, J.W., Récy, J., Taylor, F., Edwards, R.L., Cabioch, G., 1997. Abrupt changes in early Holocene tropical sea surface temperature derived from coral records. Nature 385, 705-707.

Benn, D.I., Owen, L.A., Osmaston, H.A., Seltzer, G.O., Porter, S.C., Mark, B., 2005. Reconstruction of equilibrium-line altitudes for tropical and sub-tropical glaciers. Quaternary International 138-139, 8-21.

Bostock, H.C., Opdyke, B.N., Gagan, M.K., Kiss, A.E., Fifield, L.K., 2006. Glacial/interglacial changes in the East Australia Current. Climate Dynamics 26, 645-659.

Bowler, J.M., 1976. Aridity in Australia: age, origins and expression in aeolian landforms and sediments. Earth-Science Reviews 12, 279-310.

Bowler, J.M., Wyrwoll, K.-H., Lu, Y., 2001. Variations of the northwest Australian summer monsoon over the last 300,000 years: the paleohydrological record of the Gregory (Mulan) Lakes System. Quaternary International 83-85, 63-80.

Chappell, J.M., Grindrod, A. (Eds.), 1983. Proceedings of the First CLIMANZ Conference. Department of Biogeography and Geomorphology, Australian National University, Canberra.

Chivas, A.R., García, A., van der Kaars, S., Couapel, M.J.J., Holt, S., Reeves, J.M., Wheeler, D.J., Switzer, A.D., Murray-Wallace, C.V., Banerjee, D., Price, D.M. Wang, S.X., Pearson, G., Edgar, N.T., Beaufort, L., De Deckker, P., Lawson, E., Cecil, C.B., 2001. Sea-level and environmental changes since the Last Interglacial in the Gulf of Carpentaria Australia: an overview. Quaternary International 83-85, 19-46.

Clement, A.C., Cane, M.A., Seager, R., 2001. An orbitally driven tropical source for abrupt climate change. Journal of Climate 14, 2369-2375.

Cobb, K.M., Charles, C.D., Cheng, H., Edwards, R.L., 2003. El Niño/Southern Oscillation and tropical Pacific climate during the last millennium. Nature 424, $271-$ 276.

Cohen, T.J., Nanson, G.C., Jansen, J.D., Jones, B.G., Jacobs, Z., Treble, P., Price, D.M. May, J.-H., Smith, A.M., Ayliffe, L.K., Hellstrom, J.C., 2011. Continental aridification and the vanishing of Australia's megalakes. Geology 39, 167-170.

Cohen, T.J., Nanson, G.C., Jansen, J.D., Jones, B.G., Jacobs, Z., Larsen, J.R., May, J.-H., Treble, P., Price, D.M., Smith, A.M., 2012. Late Quaternary mega-lakes fed by the northern and southern river systems of central Australia: varying moisture sources and increased continental aridity. Palaeogeography, Palaeoclimatology, Palaeoecology 356-357, 89-108

Corrège, T., Delcroix, T., Recy, J., Beck, W., Cabioch, G., Le Cornec, F., 2000. Evidence for stronger El Niño-Southern Oscillation (ENSO) events in a mid-Holocene massive coral. Paleoceanography 15, 465-480.

Corrège, T., Gagan, M.K., Beck, J.W., Burr, G.S., Cabioch, G., Le Cornec, F., 2004 Interdecadal variation in the extent of South Pacific tropical waters during the Younger Dryas event. Nature 428, 927-929.

Corrège, T., 2006. Sea surface temperature and salinity reconstruction from cora geochemical tracers. Palaeogeography, Palaeoclimatology, Palaeoecology 232. 408-428.

Croke, J., Jansen, J.D., Amos, K., Pietsch, T.J., 2010. A 100 ka record of fluvial activity in the Fitzroy River Basin, tropical northeastern Australia. Quaternary Science Reviews 30, 1681-1695.

Cruz, F.W., Burns, S.J., Karmann, I., Sharp, W.D., Vuille, M., Cardoso, A.O., Ferrari, J.A Silva Dias, P.L., Viana, O., 2005. Insolation-driven changes in atmospheric circulation over the past 116,000 years in subtropical Brazil. Nature 434, 63-66.

Dansgaard, W., 1964. Stable isotopes in precipitation. Tellus 16, 436-468.

De Deckker, P., Yokoyama, Y., 2009. Micropalaeontological evidence for Late Quaternary sea-level changes in Bonaparte Gulf, Australia. Global and Planetary Change 66, 85-92.

De Deckker, P., Chivas, A.R., Shelley, J.M.G., Torgersen, T., 1988. Ostracod shell chemistry: a new palaeoenvironmental indicator applied to a regressive/ transgressive record from the Gulf of Carpentaria, Australia. Palaeogeography, Palaeoclimatology, Palaeoecology 66, 231-241.

De Deckker, P., Tapper, N.J., van der Kaars, S., 2002. The status of the Indo-Pacific Warm Pool and adjacent land during the Last Glacial Maximum. Global and Planetary Change 35, 25-35.

De Deckker, P., Moros, M., Perner, K., Jansen, E., 2012. Influence of the tropics and the southern westerlies on glacial interhemispheric asymmetry. Nature Geoscience 5, 266-269.

de Garidel-Thoron, T., Beaufort, L., Bassinot, F., Henry, P., 2004. Evidence for large methane releases to the atmosphere from deep-sea gas-hydrate dissociation during the Last Glacial episode. Proceedings of the National Academy of Sciences 101, 9187-9192.

DeLong, K.L., Quinn, T.M., Shen, C.-C., Lin, K., 2010. A snapshot of climate variability at Tahiti at $9.5 \mathrm{ka}$ using a fossil coral from IODP Expedition 310. Geochemistry Geophysics, Geosystems 11, Q06005. http://dx.doi.org/10.1029/2009GC002758.

Devriendt, L.S.J, 2011. Late Quaternary Environment of Palaeolake Carpentaria Inferred from the Chemistry of Ostracod Valves. Unpublished MSc thesis, University of Wollongong. http://ro.uow.edu.au/theses/3319.

Ding, X., Guichard, F., Bassinot, F., Labeyrie, L., Fang, N.Q., 2002. Evolution of heat transport pathways in the Indonesian Archipelago during the last deglaciation. Chinese Science Bulletin 47, 1912-1917.
Donnelly, T., Wasson, R., 1989. CLIMANZ 3: Proceedings of the Third Symposium on the Late Quaternary Climatic History of Australasia, Parkville, Vic., 28-29 November 1987. CSIRO Division of Water Resources, Canberra, ACT, 158p.

Dunbar, G.B., Dickens, G.R., 2003a. Late Quaternary shedding of shallow marine carbonate along a tropical mixed siliciclastic-carbonate shelf: Great Barrier Reef, Australia. Sedimentology 50. http://dx.doi.org/10.1046/j.13653091.2003.00593.x.

Dunbar, G.B., Dickens, G.R., 2003b. Massive siliciclastic discharge to slopes of the Great Barrier Reef Platform during sea-level transgression: constraints from sediment cores between $15^{\circ} \mathrm{S}$ and $16^{\circ} \mathrm{S}$ latitude and possible explanations. Sedimentary Geology 162, 141-158.

Dunbar, G.B., Dickens, G.R., Carter, R.M., 2000. Sediment flux across the Great Barrier Reef shelf to the Queensland trough over the last $300 \mathrm{ky}$. Sedimentary Geology 133, 49-92.

Edwards, R.L., Chen, J.H., Wasserburg, G.J., 1987. ${ }^{238} \mathrm{U}-{ }^{234} \mathrm{U}-{ }^{230} \mathrm{Th}$ systematics and the precise measurement of time over the past 500,000 years. Earth and Planetary Science Letters 81, 175-192.

Expedition 325 Scientists, 2011. Expedition 325 summary. In: Webster, J.M., Yokoyama, Y., Cotterill, C., The Expedition 325 Scientists (Eds.), Proc. IODP, 325. Integrated Ocean Drilling Program Management International, Inc., Tokyo. http://dx.doi.org/10.2204/iodp.proc.325.101.2011.

Fielding, C.R., Trueman, J.D., Alexander, J., 2006. Holocene depositional history of the Burdekin River delta of northeastern Australia: a model for a lowaccommodation, highstand delta. Journal of Sedimentary Research 76, 411-428.

Fine, R.A., Lukas, R., Bingham, F.M., Warner, M.J., Gammon, R.H., 1994. The western equatorial Pacific: a water mass crossroads. Journal of Geophysical Research 99, 25063-25080.

Fitzsimmons, K.E., Miller, G.H., Magee, J.W., Spooner, N., 2012. Aridity in the monsoon zone as indicated by desert dune formation in the Lake Gregory (Mulan) basin, northwestern Australia. Australian Journal of Earth Sciences 59, 469-478.

Fitzsimmons, K.E., Cohen, T., Hesse, P.P., Jansen, J., Nanson, G.C., May, J.-H., Barrows, T.T., Haberlah, D., Hilgers, A., Kelly, T., Lomax, J., Treble, P., 2013. Late Quaternary palaeoenvironmental change in the Australian drylands: a synthesis. Quaternary Science Reviews 74, 78-96.

Fleitmann, D., Burns, S.J., Mudelsee, M., Neff, U., Kramers, J., Mangini, A., Matter, A., 2003. Holocene forcing of the Indian Monsoon recorded in a stalagmite from southern Oman. Science 300, 1737-1739.

Fleitmann, D., Burns, S.J., Mangini, A., Mudelsee, M., Kramers, J., Villa, I., Neff, U., AlSubbary, A.A., Buettner, A., Hippler, D., Matter, A., 2007. Holocene ITCZ and Indian monsoon dynamics recorded in stalagmites from Oman and Yemen (Socotra). Quaternary Science Reviews 26, 170-188.

Gagan, M.K., Ayliffe, L.K., Hopley, D., Cali, J.A., Mortimer, G.E., Chappell, J., McCulloch, M.T., Head, M.J., 1998. Temperature and surface-ocean water balance of the mid-Holocene tropical western Pacific. Science 279, 1014-1018

Gagan, M.K., Hendy, E.J., Haberle, S.G., Hantoro, W.S., 2004. Post-glacial evolution of the Indo-Pacific Warm Pool and the El Niño-Southern oscillation. Quaternary International 118-119, 127-143.

Gagan, M.K., Dunbar, G.B., Suzuki, A., 2012. The effect of skeletal mass accumulation in Porites on coral $\mathrm{Sr} / \mathrm{Ca}$ and $\delta^{18} \mathrm{O}$ paleothermometry. Paleoceanography 27, PA1203. http://dx.doi.org/10.1029/2011PA002215.

Gingele, F.X., De Deckker, P., 2004. Fingerprinting Australia's rivers with clay minerals and the application for the marine record of climate change. Australian Journal of Earth Sciences 51, 339-348.

Gingele, F.X., De Deckker, P., Hillenbrand, C.-D., 2001. Late Quaternary fluctuations of the Leeuwin Current and palaeoclimates on the adjacent land masses: clay mineral evidence. Australian Journal of Earth Sciences 48, 867-874.

Gingele, F.X., De Deckker, P., Girault, A., Guichard, F., 2002. History of the South Java Current over the past $80 \mathrm{ka}$. Palaeogeography, Palaeoclimatology, Palaeoecology $183,247-260$

Godfrey, J.S., Ridgway, K.R., 1985. The large-scale environment of the poleward-flowing Leeuwin current, Western Australia - longshore steric height gradients, wind stresses and geostrophic flow. Journal of Physical Oceanography 15, 481-495.

Gordon, A.L., Fine, R.A., 1996. Pathways of water between the Pacific and Indian oceans in the Indonesian seas. Nature 379, 146-149.

Griffiths, M.L., Drysdale, R.N., Gagan, M.K., Zhao, J-X., Ayliffe, L.K., Hellstrom, J.C. Hantoro, W.S., Frisia, S., Feng, Y.-X., Cartwright, I., St Pierre, E., Fischer, M.J., Suwargadi, B.W., 2009. Increasing Australian-Indonesian monsoon rainfall linked to early Holocene sea-level rise. Nature Geoscience 2, 636-639.

Griffiths, M.L., Drysdale, R.N., Gagan, M.K., Frisia, S., Zhao, J.-X., Ayliffe, L.K., Hantoro, W.S., Hellstrom, J.C., Fischer, M.J., Feng, Y.-X., Suwargadi, B.W., 2010a. Evidence for Holocene changes in Australian-Indonesian monsoon rainfall from stalagmite trace element and stable isotope ratios. Earth and Planetary Science Letters 292, 27-38.

Griffiths, M.L., Drysdale, R.N., Gagan, M.K., Zhao, J., Hellstrom, J.C., Ayliffe, L., Hanton, W.S., 2013. Abrupt increase in east Indonesian rainfall from flooding of the Sunda Shelf $\sim 9,500$ years ago. Quaternary Science Reviews 74, 273279.

Griffiths, M.L., Drysdale, R.N., Vonhof, H.B., Gagan, M.K., Zhao, J.-X., Ayliffe, L.K., Hantoro, W.S., Hellstrom, J.C., Cartwright, I., Frisia, S., Suwargadi, B.W., 2010b. Younger Dryas-Holocene temperature and rainfall history of southern Indonesia from $\delta^{18} \mathrm{O}$ in speleothem calcite and fluid inclusions. Earth and Planetary Science Letters 295, 30-36.

Grindrod, J., Moss, P., van der Kaars, S., 1999. Late Quaternary cycles of mangrove development and decline on the north Australian continental shelf. Journal of Quaternary Science 14, 465-470. 
Grindrod, J., Moss, P.T., van der Kaars, S., 2002. Late Quaternary mangrove pollen records from the continental shelf and deep ocean cores in the north Australian region. In: Kershaw, A.P., David, B., Tapper, T., Penny, D., Brown, J. (Eds.), Bridging Wallace's Lines - the Environmental and Cultural History and Dynamics of the SE-Asian-Australian Region. Advances in Geoecology, vol. 34. Cantena Verlag, Reiskirchen, Germany, pp. 119-148.

Haberle, S.G., 1998. Late Quaternary vegetation change in the Tari Basin, Papua New Guinea. Palaeogeography, Palaeoclimatology, Palaeoecology 167, 1-24.

Haberle, S.G., 2005. A 23 000-yr record from Lake Euramoo, Wet Tropics of NE Queensland, Australia. Quaternary Research 64, 343-356.

Haberle, S.G., Rowe, C., Proske, U., 2011. Palaeoecological research in the Kimberley. In: Prog. Abstr. The Kimberley Foundation of Australia Scientific Advisory Board Workshop. University of Western Australia, Perth, Australia. 17th-18th November 2011

Harris, P.T., Heap, A.D., Marshall, J.F., McCulloch, M., 2008. A new coral reef province in the Gulf of Carpentaria, Australia: colonisation, growth and submergence during the early Holocene. Marine Geology 251, 85-97.

Hathorne, E.C., Felis, T., James, R.H., Thomas, A., 2011. Laser ablation ICP-MS screening of corals for diagenetically altered areas applied to Tahiti corals from the last deglaciation. Geochimica Cosmochimica Acta 75, 1490-1506.

Haug, G.H., Hughen, K.A., Sigman, D.M., Peterson, L.C., Rohl, U.L., 2001. Southward migration of the Intertropical Convergence Zone through the Holocene. Science 293, 1304-1308.

Hendy, E.J., Gagan, M.K., Alibert, C.A., McCulloch, M.T., Lough, J.M., Isdale, P.J., 2002. Abrupt decrease in tropical Pacific sea surface salinity at end of little ice age. Science 295, 1511-1514.

Hendy, E.J., Lough, J.M., Gagan, M.K., 2003. Chronological control of coral records using luminescent lines and evidence for non-stationary ENSO teleconnections in northeast Australia. The Holocene 13, 187-199.

Hesse, P.P., 2010. The Australian desert dunefields: formation and evolution in an old, flat, dry continent. In: Bishop, P., Pillans, B. (Eds.), Australian Landscapes. Geological Society, London, pp. 141-163.

Hocknull, S.A., Zhao, J.-x., Feng, Y.-X, Webb, G.E., 2007. Responses of Quaternary rainforest vertebrates to climate change in Australia. Earth and Planetary Science Letters 264, 317-331.

Holbourn, A., Kuhnt, W., Kawamura, H., Jian, Z., Grootes, P.M., Erlenkeuser, H., Xu, J., 2005. Orbitally paced paleo-productivity variations in the Timor Sea and Indonesian Throughflow variability during the last 460 kyr. Paleoceanography 20, PA3002. http://dx.doi.org/10.1029/2004PA001094.

Hope, G.S., Peterson, J.A., 1975. Glaciation and vegetation in the high New Guinea mountains. In: Suggate, R.P., Cresswell, M.M. (Eds.), Quaternary Studies. The Royal Society of New Zealand, Wellington, pp. 155-162.

Hope, G., Tulip, J., 1994. A long vegetation history from lowland Irian Jaya, Indonesia. Palaeogeography, Palaeoclimatology, Palaeoecology 109, 385-398.

Hope, G.S., 1976. The vegetational history of Mt Wilhelm, Papua New Guinea. The Journal of Ecology 64, 627-663.

Hope, G., 1989. Climatic implications of timberline changes in Australasia from 30 000 BP to present. In: Donnelly, T., Wasson, R. (Eds.), CLIMANZ 3. CSIRO Division of Water Research, Canberra, pp. 91-99.

Hope, G., 2009. Environmental change and fire in the Owen Stanley ranges, Papua New Guinea. Quaternary Science Reviews 28, 2261-2276.

Hopley, D., Smithers, S.G., Parnell, K., 2007. Geomorphology of the Great Barrier Reef: Development, Diversity and Change. Cambridge University Press.

Jones, B.G., Woodroffe, C.D., Martin, G.R., 2003. Deltas in the Gulf of Carpentaria, Australia: Forms, Processes, and Products. SEPM Special Publication 76. 21-43.

Jorry, S., Droxler, A.W., Mallarino, G., Dickens, G.R., Bentley, S.J., Beaufort, L., Peterson, L.C., Opdyke, B.N., 2008. Bundled turbidite deposition in the central Pandora Trough (Gulf of Papua) since Last Glacial Maximum: linking sediment nature and accumulation to sea level fluctuations at millennial timescale. Journal of Geophysical Research 113, F01S19. http://dx.doi.org/10.1029/ 2006JF000649.

Kershaw, A.P., Bretherton, S.C., van der Kaars, S., 2007. A complete pollen record of the last 230 ka from Lynch's Crater, north-eastern Australia. Palaeogeography, Palaeoclimatology, Palaeoecology 251, 23-45.

Kershaw, A.P., 1976. A Late Pleistocene and Holocene pollen diagram from Lynch's Crater, north-eastern Queensland, Australia. New Phytologist 77, 469-498.

Kershaw, A.P., 1981. Quaternary vegetation and environments. In: Keast, A. (Ed.), Ecological Biogeography of Australia. Monographiae Biologicae 41, vol. 1. Dr W. Junk, The Hague, pp. 81-101.

Koutavas, A., Lynch-Stieglitz, J., Marchitto, T.M., Sachs, J.P., 2002. El Niño-like pattern in ice age tropical Pacific sea surface temperature. Science 297, 226-230.

Lachinet, M.S., 2009. Climatic and environmental controls on speleothem oxygenisotope values. Quaternary Science Reviews 28, 412-432.

Lea, D.W., Pak, D.K., Spero, H.J., 2000. Climate impact of the late Quaternary equatorial Pacific sea surface temperature variations. Science 289, 1719-1724.

Leduc, G., Schneider, R., Kim, J.-H., Lohmann, G., 2010. Holocene and Eemian sea surface temperature trends as revealed by alkenon and $\mathrm{Mg} / \mathrm{Ca}$ paleothermometry. Quaternary Science Reviews 29, 989-1004.

Lees, B.G., Lu, Y.C., 1991. Quaternary Aeolian deposits in the Gulf of Carpentaria region, northern Australia. Kexue Tongbao 36, 1484-1486.

Lees, B.G., Lu, Y.C., 1992. A preliminary study on formation of the sand dune systems in the northern Australian coastal zone. Chinese Science Bulletin 37, 587-592.

Lees, B.G., Head, J., Ly, Y.C., 1990. Reconnaissance thermoluminescence dating of northern Australian coastal dune systems. Quaternary Research 34, 169-185.
Lees, B.G., 1992. Geomorphological evidence for late Holocene climate change in northern Australia. Australian Geographer 23, 1-11.

Lees, B.G., 2006. Timing and formation of coastal dunes in Northern and Eastern Australia. Journal of Coastal Research 22, 78-89.

Levi, C., Labeyrie, L., Guichard, L., Cortijo, E., Waelbroeck, C., Caillon, N., Duprat, J., de Garidel-Thoron, T., Elderfield, H., 2007. Low-latitude hydrological cycle and rapid climate change during the last deglaciation. Geochemistry, Geophysics, Geosystems 8, Q05N12. http://dx.doi.org/10.1029/2006GC001514.

Lewin, J., Macklin, M.G., Johnstone, E., 2005. Interpreting alluvial archives: sedmentological factors in the British Holocene fluvial record. Quaternary Science Reviews 24, 1873-1889.

Lewis, S.C., Gagan, M.K., Ayliffe, L.K., Zhao, J.-X., Hantoro, W.S., Treble, P.C. Hellstrom, J.C., LeGrande, A.N., Kelley, M., Schmidt, G.A., 2011. High-resolution stalagmite reconstructions of Australian-Indonesian monsoon rainfall variability during Heinrich stadial 3 and Greenland interstadial 4. Earth and Planetary Science Letters 303, 133-142.

Lewis, S.E., Wüst, R.A.J., Webster, J.M., Shields, G.A., Renema, W., Lough, J.M., Jacobsen, G., 2012. Development of an inshore fringing coral reef using textural, compositional and stratigraphic data from Magnetic Island, Great Barrier Reef, Australia. Marine Geology 299-302, 18-32.

Lewis, S.E., Sloss, C.R., Murray-Wallace, C.V., Woodroffe, C.D., Smithers, S.G., 2013 Postglacial sea-level change around the Australian mainland. Quaternary Science Reviews 74, 115-138.

Linsley, B.K., Thunell, R.C., 1990. The record of deglaciation in the Sulu Sea: evidence for the Younger Dryas event in the tropical western Pacific. Paleoceanography 5 1025-1039.

Linsley, B.K., Rosenthal, Y., Oppo, D., 2010. Holocene evolution of the Indonesian Throughflow and the western Pacific warm pool. Nature Geoscience 3, 578583.

Liu, Z., Zhang, Q., Wu, L., 2004. Remote impact on tropical Atlantic climate variability: statistical assessment and dynamical assessment. Journal of Climate 17 $1529-1549$

Lough, J.M., 2007. Tropical river flow and rainfall reconstructions from coral luminescence: Great Barrier Reef, Australia. Paleoceanography 22, PA2218.

Luckge, A., Mohtadi, M., Rühlemann, C., Scheeder, G., Vink, A., Reinhardt, L. Wiedecke, M., 2009. Monsoon versus ocean circulation controls on paleoenvironmental conditions off southern Sumatra during the past 300,000 years. Paleoceanography 24, PA1208. http://dx.doi.org/10.1029/2008PA001627.

Luly, J.G., Grindrod, J., Penny, D., 2006. Holocene palaeoenvironments and change a Three-Quarter Mile Lake, Silver Plains Station, Cape York Peninsula, Australia. The Holocene 16, 1085-1094.

Lybolt, M., Neil, D., Zhao, J.-X., Feng, Y.-X., Yu, K.-F., Pandolfi, J., 2010. Instability in a marginal coral reef: the shift from natural variability to a human-dominated seascape. Frontiers in Ecology and the Environment. http://dx.doi.org/10.1890/ 090176

Magee, J.W., Miller, G.H., Spooner, N.A., Questiaux, D., 2004. Continuous 150 k.y. monsoon record from Lake Eyre, Australia: Insolation-forcing implications and unexpected Holocene failure. Geology 32, 885-888.

MARGO Project Members, 2009. Constraints on the magnitude and patterns of ocean cooling at the Last Glacial Maximum. Nature Geoscience 2, 127-132.

Marshall, A.G., Lynch, A.H., 2006. Time-slice analysis of the Australian summe monsoon during the late Quaternary using the Fast Ocean Atmosphere Model. Journal of Quaternary Science 21, 789-801.

Marshall, A.G., Lynch, A.H., 2008. The sensitivity of the Australian summer monsoon to climate forcing during the late Quaternary. Journal of Geophysical Research 113, D11107. http://dx.doi.org/10.1029/2007JD008981.

Martinez, J.I., De Deckker, P., Chivas, A.R., 1997. New estimates for salinity changes in the western Pacific warm pool during the Last Glacial Maximum: oxygen isotope evidence. Marine Micropaleontology 32, 311-340.

Martinez, J.I., Taylor, L., De Deckker, P., Barrows, T., 1998. Planktonic foraminiferal from the Eastern Indian Ocean: distribution and ecology in relation to the western Pacific warm pool (WPWP). Marine Micropaleontology 34, 121-151.

Martinez, J.I., De Deckker, P., Barrows, T., 1999. Paleoceanography of the Last Glacia Maximum in the eastern Indian Ocean: planktonic foraminifera evidence. Palaeogeography Palaeoclimatology Palaeoecology 147, 73-99.

McCulloch, M.T., De Deckker, P., Chivas, A.R., 1989. Strontium variations in single ostracod valves from the Gulf of Carpentaria, Australia: a palaeoenvironmental indicator. Geochimica et Cosmochimica Acta 53, 1703-1710.

McCulloch, M.T., Tudhope, A.W., Esat, T.M., Mortimer, G.E., Chappell, J., Pillans, B. Chivas, A.R., Omura, A., 1996. Coral record of equatorial sea-surface temperatures during the penultimate deglaciation at Huon Peninsula. Science 283 202-204.

McDermott, F., 2004. Palaeo-climate reconstructions from stable isotope variations in speleothems: a review. Quaternary Science Reviews 23, 901-918.

McGregor, H.V., Gagan, M.K., 2004. Western Pacific coral $\delta^{18} \mathrm{O}$ record of anomalous Holocene variability in the El Niño-Southern Oscillation. Geophysical Research Letters 31, L11204. http://dx.doi.org/10.1029/2004GL019972.

McGregor, H.V., Gagan, M.K., McCulloch, M.T., Hodge, E., Mortimer, G., 2008. MidHolocene variability in the marine ${ }^{14} \mathrm{C}$ reservoir age for northern coastal Papua New Guinea. Quaternary Geochronology 3, 213-225.

McGregor, H.V., 2011. Palaeoclimate from corals. In: Hopley, D. (Ed.), Encyclopedia of Modern Coral Reefs. Springer, Dordrecht, Netherlands, pp. 777-785.

McPhaden, M., Bahr, F. du Penhoat, Y., Firing, E., Hayes, S., Niiler, P., Richardson, P. Toole, J., 1992. The response of the western equatorial Pacific Ocean to westerly 
wind bursts during November 1989 to January 1990. Journal of Geophysical Research 97, 14289-14303.

Miller, G.H., Magee, J.W., Tull, A.J.T., 1997. Low-latitude glacial cooling in the Southern Hemisphere from amino-acid racemization in emu eggshells. Nature 385, 241-244.

Mohtadi, M., Oppo, D.W., Steinke, S., Stuut, J.-B.W., De Pol-Holz, R., Hebbeln, D., Lückge, A., 2011. Glacial to Holocene swings of the Australian-Indonesian monsoon. Nature Geoscience 4, 540-544.

Monnin, E., Indermühle, A., Dällenbach, A., Flückiger, J., Stauffer, B., Stocker, T.F., Raynaud, D., Barnola, J.-M., 2001. Atmospheric $\mathrm{CO}_{2}$ concentrations over the Last Glacial terminations. Science 291, 112-114.

Mooney, S.D., Harrison, S.P., Bartlein, P.J., Daniau, A.-L., Stevenson, J., Brownlie, K.C., Buckman, S., Cupper, M., Luly, J., Black, M., Colhoun, E., D’Costa, D., Dodson, J., Haberle, S., Hope, G.S., Kershaw, P., Kenyon, C., McKenzie, M., Williams, N., 2011. Late Quaternary fire regimes in Australia. Quaternary Science Reviews 30, 2846.

Moreno, E., Bassinot, F., Baudin, F., Vénec-Peyré, M.-T., 2008. Influence of orbital forcing and sea level changes on sedimentation patterns in the Timor Sea during the last 260 ka. Paleoceanography 23, PA1207. http://dx.doi.org/10.1029/ 2007 PA001423.

Moss, P.T., Cosgrove, R., Ferrier, A., Haberle, S., 2012. Holocene environments of the schlerophyll woodlands of the Wet Tropics of northeastern Australia. In: Haberle, S.G., David, B. (Eds.), Peopled Landscapes. Archaeological and Biogeographic Approaches to Landscapes. Terra Australis, 34. ANU ePress, Canberra Australia, pp. 329-341.

Moss, P.T., Kershaw, A.P., 2000. The Last Glacial cycle from the humid tropics of northeastern Australia: comparison of a terrestrial and a marine record. Palaeogeography, Palaeoclimatology, Palaeoecology 155, 155-176.

Moss, P.T., Kershaw, A.P., 2007. A late Quaternary marine palynological record (Oxygen Isotope Stages 1 to 7 ) for the humid tropics of northeastern Australia based on ODP Site 820. Palaeogeography, Palaeoclimatology, Palaeoecology 251, 4-22.

Moy, C.M., Seltzer, G.O., Rodbell, D.T., Anderson, D.M., 2002. Variability of El Niño/ Southern Oscillation activity at millennial timescales during the Holocene epoch. Nature 402, 162-165.

Müller, A., Opdyke, B.N., 2000. Glacial-interglacial changes in the nutrient utilization and palaeo-productivity in the Indonesian Throughflow sensitive Timor Trough, easternmost Indian Ocean. Paleoceanography 15, 85-94.

Murgese, D.S., De Deckker, P., Spooner, M.I., Young, M., 2008. A 35,000 year record of changes in the eastern Indian Ocean offshore Sumatra. Palaeogeography Palaeoclimatology Palaeoecology 265, 195-213.

Nanson, G.C., Price, D.M., Short, S.A., Young, R.W., Jones, B.J., 1991. Comparative uranium thorium and thermoluminescence dating of weathered Quaternary alluvium in the tropics of northern Australia. Quaternary Research 35, 347366.

Nanson, G.C., East, T.J., Roberts, R.G., 1993. Quaternary stratigraphy, geochronology and evolution of the Magela Creek catchment in the monsoon tropics of northern Australia. Sedimentary Geology 83, 277-302.

Nanson, G.C., Jones, B.J., Price, D.M., Pietsch, T.J., 2005. Rivers turned to rock: Late Quaternary alluvial induration influencing the behaviour and morphology of an anabranching river in the Australian monsoon tropics. Geomorphology 70, 398-420.

Nanson, G.C., Price, D.M., Jones, B.G., Maroulis, J.C., Coleman, M., Bowman, H., Cohen, T.J., Pietsch, T.J., Larsen, J.R., 2008. Alluvial evidence for major climate and flow regime changes during the middle and late Quaternary in eastern central Australia. Geomorphology 101, 109-129.

Newsome, J., Flenley, J.R., 1988. Late Quaternary vegetational history of the Central Highlands of Sumatra. II. Palaeopalynology and vegetational history. Journal of Biogeography 15, 555-578.

Nott, J.F., Price, D.M., 1994. Plunge pools and paleoprecipitation. Geology 22, $1047-$ 1050.

Nott, J.F., Price, D.M., 1999. Waterfalls, floods and climate change: evidence from tropical Australia. Earth and Planetary Science Letters 171, 267-276.

Nott, J.F., Price, D.M., Bryant, E.A., 1996. A 30,000 year record of extreme floods in tropical Australia from relict plunge pool deposits: implications for future climate change. Geophysical Research Letters 23, 379-382.

Page, M.C., Dickens, G.R., Dunbar, G.B., 2003. Tropical view of Quaternary sequence stratigraphy: siliciclastic accumulation on slopes east of the Great Barrier Reef since the Last Glacial Maximum. Geology 31, 1013-1016.

Partin, J.W., Cobb, K.M., Adkins, J.F., Clark, B., Fernandez, D.P., 2007. Millennial-scale trends in west Pacific warm pool hydrology since the Last Glacial Maximum. Nature 449, 452-455.

Patrick, A., Thunell, R.C., 1997. Tropical Pacific sea surface temperatures and upper water column thermal structure during the Last Glacial Maximum. Paleoceanography $12,649-657$.

Peerdeman, F.M., Davies, P.J., Chivas, A.R., 1993. The stable isotope signal in the shallow-water, upper-slope sediments off the Great Barrier Reef (Hole 820A). In: McKenzie, J.A., Davies, P.J., Palmer-Julson, A., et al., (Eds.), Proceedings of the Ocean Drilling Program, vol. 133. Scientific Results, pp. 163-173.

Perry, C.T., Smithers, S.G., 2011. Cycles of coral reef 'turn-on', rapid growth and 'turn-off over the past 8500 years: a context for understanding modern ecological states and trajectories. Global Change Biology 17, 76-86. http:// dx.doi.org/10.1111/j.1365-2486.2010.02181.x.

Petherick, L., Bostock, H.C., Cohen, T.J., Fitzsimmons, K.E., Tibby, J., Moss, P., Mooney, S., Barrows, T.T., Reeves, J.M., Kemp, J., Jansen, J.D., Nanson, G., De
Deckker, P., Fletcher, M., Dosseto, A., OZ-INTIMATE Members, 2013. Temperate records from Australia on INTIMATE timescales: a summary. Quaternary Science Reviews 74, 58-77.

Prebble, M., Sim, R., Finn, J., Fink, D., 2005. A Holocene pollen and diatom record from Vanderlin Island, Gulf of Carpentaria, lowland tropical Australia. Quaternary Research 64, 357-371.

Prentice, M.L., Hope, G.S., Maryunani, K., Peterson, J.A., 2005. An evaluation of snowline data across New Guinea during the last major glaciation, and areabased glacier snowlines in the Mt. Jaya region of Papua, Indonesia, during the Last Glacial Maximum. Quaternary International 138-139, 93-117.

Prentice, M.L., Hope, G.S., Peterson, J.A., Barrows, T.T., 2011. The glaciation of the south-east Asian equatorial region. In: Ehlers, J., Gibbard, P.L., Hughes, P.D. (Eds.), Developments in Quaternary Sciences. Elsevier, pp. 1023-1036 (Chapter 73).

Reeves, J.M., Chivas, A.R., Garcia, A., De Deckker, P., 2007. Palaeoenvironmental change in the Gulf of Carpentaria (Australia) since the Last Interglacial based on Ostracoda. Palaeogeography, Palaeoclimatology, Palaeoecology 246, 163187.

Reeves, J.M., Chivas, A.R., Garcia, A., Holt, S., Couapel, M.J.J., Jones, B.G., Cendón, D.I., Fink, D., 2008. The sedimentary record of palaeoenvironments and sea-level change in the Gulf of Carpentaria, Australia, through the Last Glacial cycle. Quaternary International 183, 3-22.

Reeves, J., Barrows, T.T., Cohen, T.J., Kiem, A.S., Bostock, H.C., Fitzsimmons, K.E., Jansen, J.D., Krause, C., Petherick, L., Phipps, S.J., OZ-INTIMATE Members, 2013. Climate variability recorded in marine and terrestrial archives in the Australian region over the last 35, 000 years: an OZ-INTIMATE compilation. Quaternary Science Reviews 74, 21-34.

Rowe, C., 2007. Vegetation change following mid-Holocene marine transgression of the Torres Strait shelf: a record from the island of Mua, northern Australia. The Holocene 17, 927-937.

Rozanski, K., Araguasaraguas, L., Gonfiantini, R., 1992. Relation between long-term trends of 0-18 isotope composition of precipitation and climate. Science 258, 981-985.

Saji, H.H., Goswami, B.N., Vinayachandran, P.H., Yamagata, T., 1999. A dipole mode in the tropical Indian Ocean. Nature 401, 360-363.

Shulmeister, J., Lees, B., 1995. Pollen evidence from tropical Australia for the onset of an ENSO-dominated climate at c. 4000 BP. The Holocene 5, 10-18.

Spooner, M.I., Barrows, T.T., De Deckker, P., Paterne, M., 2005. Palaeoceanography of the Banda Sea, and Late Pleistocene initiation of the Northwest Monsoon. Global and Planetary Change 49, 28-46.

Spooner, M.I., De Deckker, P., Barrows, T.T., Lifield, L.K., 2011. The behaviour of the Leeuwin Current offshore NW Australia during the last five glacial-interglacial cycles. Global and Planetary Change 75, 119-132.

Stott, L., Poulsen, C., Lund, S., Thunell, R., 2002. Super ENSO and global climate oscillation at millennial time scales. Science 297, 222-226.

Stott, L., Cannariato, K., Thunell, R., Haug, G.H., Koutavas, A., Lund, S., 2004. Decline of surface temperature and salinity in the western tropical Pacific Ocean in the Holocene epoch. Nature 431, 56-59.

Stott, L., Timmermann, A., Thunell, R., 2007. Southern Hemisphere and deep-sea warming led deglacial atmospheric $\mathrm{CO}_{2}$ rise and tropical warming. Science 318, 435-438.

Sturman, A., Tapper, N., 1996. The Weather and Climate of Australia and New Climate of Australia and New Zealand. Oxford University Press, Melbourne.

Tachikawa, K., Vidal, L., Sonzogni, Bard, E., 2009. Glacial/interglacial sea surface temperature changes in the southwest Pacific Ocean over the past $360 \mathrm{ka}$. Quaternary Science Reviews 28, 1160-1170.

Thom, B.G., Chappell, J., 1975. Holocene sea levels relative to Australia. Search 6, 90-93.

Thomas, M.F., Nott, J., Price, D.M., 2001. Late Quaternary stream sedimentation in the humid tropics: a review with new data from NE Queensland, Australia. Geomorphology 39, 53-68.

Thunell, R., Anderson, D., Gellar, D., Miao, Q., 1994. Sea-surface temperature estimates for the tropical western Pacific during the last glaciation and their implications for the Pacific warm pool. Quaternary Research 41, 255-264.

Tomczak, M., Godfrey, J.S., 1994, 2005. Regional Oceanography: an Introduction. Pergamon Press, Oxford.

Torgersen, T., Jones, M.R., Stephens, A.W., Searle, D.E., Ullman, W.J., 1985. Late Quaternary hydrological changes in the Gulf of Carpentaria. Nature 313, 785787.

Torgersen, T., Luly, J., De Deckker, P., Jones, M.R., Searle, D.E., Chivas, A.R., Ullman, W.J., 1988. Late Quaternary environments of the Carpentaria basin, Australia. Palaeogeography, Palaeoclimatology, Palaeoecology 67, 245-261.

Tudhope, A.W., Chilcott, C.P., McCulloch, M.T., Cook, E.R., Chappell, J., Ellam, R.M., Lea, D.W., Lough, J.M., Shimmield, G.B., 2001. Variability in the El NinoSouthern Oscillation through the glacial-interglacial cycle. Science 291, 1511-1517.

Turney, C.S.M., Kershaw, A.P., Clemens, S.C., Branch, N., Moss, P.T., Fifield, L.K., 2004. Millennial and orbital variations of El Niño/Southern Oscillation and highlatitude climate in the Last Glacial period. Nature 428, 306-310.

Turney, C.S.M., Kershaw, A.P., Lowe, J.J., van der Kaars, S., Johnston, R., Rule, S., Moss, P., Radke, L., Tibby, J., McGlone, M.S., Wilmshurst, J.M., Vandergoes, M.J., Fitzsimons, S.J., Bryant, C., James, S., Branch, N.P., Cowley, J., Kalin, R.M., Ogle, N., Jacobsen, G., Fifield, K.L., 2006. Climatic variability in the southwest Pacific during the Last Termination (20-10 ka BP). Quaternary Science Reviews 25, 886-903. 
van der Kaars, S., De Deckker, P., 2002. A Late Quaternary pollen record from deepsea core Fr10/95, GC17 offshore Cape Range Peninsula, northwestern Western Australia. Review of Palaeobotany and Palynology 120, 17-39.

van der Kaars, S., Wang, X., Kershaw, P., Guichard, F., Setiabudi, D.A., 2000. A Late Quaternary palaeoecological record from the Banda Sea, Indonesia: patterns of vegetation, climate and biomass burning in Indonesia and northern Australia. Palaeogeography, Palaeoclimatology, Palaeoecology 155, 135-147.

van der Kaars, S., Penny, D., Tibby, J., Fluin, J., Dam, R., Suparan, P., 2001. Late Quaternary palaeoecology, palynology and palaeolimnology of a tropical lowland swamp: Rawa Danau, West-Java, Indonesia. Palaeogeography, Palaeoclimatology, Palaeoecology 171, 185-212.

van der Kaars, S., De Deckker, P., Gingele, F.Z., 2006. A 100,000-year record of annual and seasonal rainfall and temperature for northwestern Australia based on a pollen record obtained offshore. Journal of Quaternary Science 21, 879-889.

van der Kaars, S., Bassinot, F., De Deckker, P., Guichard, F., 2010. Changes in monsoon and ocean circulation and the vegetation cover of southwest Sumatra through the last 83,000 years: the record form marine core BAR94-42. Palaeogeography, Palaeoclimatology, Palaeoecology 296, 52-78.

van der Kaars, S., Williams, M.A.J., Bassinot, F., Guichard, F., Moreno, E., Dewilde, F. Cook, E.K., 2012. The influence of the $\sim 73 \mathrm{ka}$ Toba super-eruption on the ecosystems of northern Sumatra as recorded in marine core BAR94-25. Quaternary International 258, 45-53.

Veth, P. Smith, M., Bowler, J., Fitzsimmons, K.E. Williams, A., Hiscock, P., 2009. Excavations at Parnkupirti, Lake Gregory, Great Sandy Desert: OSL ages for occupation before the Last Glacial Maximum. Australian Archaeology 69, 1-10.

Visser, K., Thunell, R., Stott, L., 2003. magnitude and timing of temperature change in the Indo-Pacific Warm Pool during the deglaciation. Nature 421, 152-155.

Walker, D., Flenley, J.R., 1979. Late Quaternary vegetational history of the Enga Province of upland Papua-New-Guinea. Philosophical Transactions of the Royal Society of London Series B-Biological Sciences 286, 265-344.

Walker, D. (Ed.), 1972. Bridge and Barrier, The Natural and Cultural History of Torres Strait. Department of Biogeography and Geomorphology, The Australian National University, Canberra. Publ. BG/3.

Wang, Y.T., Cheng, H., Edwards, R.L., An, Z.S., Wu, J.Y., Shen, C.-C., Dorale, J.A., 2001 A high-resolution absolute-dated late Pleistocene monsoon record from Hulu Cave, China. Science 294, 2345-2348.

Wang, Y., Cheng, H., Edwards, R.L., He, Y., Kong, X., An, Z., Wu, J., Kelly, M.J. Dykoski, C.A., Li, Z., 2005. The Holocene Asian monsoon; links to solar changes in the North Atlantic climate. Science 308, 854-857.

Wang, Y., Cheng, H., Edwards, R.L., Kong, X., Shao, X., Chen, S., Wu, J., Jiang, X. Wang, X., An, Z., 2008. Millennial- and orbital-scale changes in the East Asian monsoon over the past 224,000 years. Nature 451, 1090-1093.

Wang, B. (Ed.), 2006. The Asian Monsoon. Springer Praxis, Chichester.

Ward, I.A.K., Nanson, G.C., Head, L.M., Fullagar, R.L.K., Price, D.M., Fink, D., 2005. Late Quaternary landscape evolution in the Keep River region, northwestern Australia. Quaternary Science Reviews 24, 1906-1922.

Wasson, R.J. (Ed.), 1992. Modern Sedimentation and Late Quaternary Evolution of the Magela Creek Plain. Australian Government Publishing Service, Office of the Supervising Scientist for the Alligator Rivers Region. Research Report 6.
Weaver, A.J., Saenko, O.A., Clark, P.U., Mitrovica, J.X., 2003. Meltwater pulse 1A from Antarctica as a trigger of the Bølling-Allerød warm interval. Science 299 1709-1713.

Webster, P.J., Chang, H.-R., 1997. Atmospheric wave propagation in heterogeneous flow: basic flow controls on tropical-extratropical interaction and equatorial wave modification. Dynamics of Atmospheres and Oceans 27, 91-134.

Webster, P.J., Streten, N.A., 1978. Late Quaternary ice age climates of tropical Australasia: Interpretations and reconstructions. Quaternary Research 10, 279-309.

Webster, P.J., Moore, M.D., Loschnigg, J.P., Leben, R.R., 1999. Coupled oceanatmosphere dynamics in the Indian Ocean during 1997-98. Nature 401, 356-360.

Wende, R., Nanson, G.C., Price, D.M., 1998. Aeolian and fluvial evidence for Late Quaternary environmental change in the east Kimberley of Western Australia. Australian Journal Earth Sciences 44, 519-526.

Wijffels, S.E., Bray, N., Hautala, S., Mayers, G., Morawitz, W.M.L., 1996. The WOCE Indonesian Throughflow repeat hydrology sections I10 and IR6. International WOCE Newsletter 24, 25-28.

Wijffels, S., Sprintall, J., Fieux, M., Bray, N., 2002. The JADE and WOCE I10/IR6 throughflow sections in the southeast Indian Ocean. Part 1: water mass distribution and variability. Deep-Sea Research II 49, 1341-1362.

Williams, M., Cook, E., van der Kaars, S., Barrows, T., Shulmeister, J., Kershaw, P. 2009. Glacial and deglacial climatic patterns in Australia and surrounding regions from 35000 to 10000 years age reconstructed from terrestrial and nearshore proxy data. Quaternary Science Reviews 28, 2398-2419.

Williams, A.N., Ulm, S., Goodwin, I.D., Smith, M., 2010. Hinter-gatherer response to late Holocene climatic variability in northern and central Australia. Journal of Quaternary Science 25, 831-838.

Woodroffe, C.D., Thom, B.G., Chappell, J., 1985. Development of widespread mangroves and swamps in the mid-Holocene times in northern Australia. Nature 317, 711-713.

Woodroffe, C.D. Beech, M.R. Gagan, M.K. 2003. Mid-late Holocene El Niño variability in the equatorial Pacific from coral microatolls. Geophysical Research Letters 30, 1358. http://dx.doi.org/10.1029/2002GL015868.

World Ocean Atlas, 2005. http://www.nodc.noaa.gov/OC5/WOA05/pr_woa05.html

Wyrwoll, K.-H., Miller, G.H., 2001. Initiation of the Australian summer monsoon 14,000 years ago. Quaternary International 83-85, 119-128.

Xu, J., Kuhnt, W., Holbourn, A., Regenberg, M., Andersen, N., 2010. Indo-Pacific Warm Pool variability during the Holocene and Last Glacial Maximum. Paleoceanography 25, PA4230. http://dx.doi.org/10.1029/2010PA001934.

Yan, X.H., Ho, C.R., Zheng, Q., Klemas, V., 1992. Temperature and size variabilities of the western Pacific warm pool. Science 258, 1643-1645.

Yokoyama, Y., Purcell, A., Lambeck, K., Johnston, P., 2001. Shore-line reconstruction around Australia during the Last Glacial Maximum and Late Glacial Stage. Quaternary International 83-85, 9-18.

Zhang, P.Z., Cheng, H., Edwards, R.L., Chen, F.H., Wang, Y.J., Yang, X.L., Liu, J., Tan, M., Wang, X.F., Liu, J.H., An, C.L., Dai, Z.B., Zhou, J., Zhang, D.Z., Jia, J.H., Jin, L.Y, Johnson, K.R., 2008. A test of climate, sun, and culture relationships from an 1810-year Chinese Cave record. Science 322, 940-942.

Zuvela-Aloise, M., 2005. Modelling of the Indonesian Throughflow on glacialinterglacial time-scales. Unpublished PhD thesis, University of Kiel. 